\title{
Learning by Lending *
}

\author{
Matthew Botsch ${ }^{\dagger} \quad$ Victoria Vanasco ${ }^{\ddagger}$
}

March 20, 2018

\begin{abstract}
This paper studies bank learning through repeated interactions with borrowers from a new perspective. To understand learning by lending, we adapt a methodology from labor economics to analyze how loan contract terms evolve as banks acquire new information about borrowers. We construct "proxy" variables for this information using data from borrowers' out-of-sample, future credit performance. Due to the timing of their construction, banks could not have used these variables directly to price loans. We nonetheless find that these proxies increasingly predict loan prices as relationships progress, even after controlling for possible omitted variable bias. Our methodology provides strong evidence that: (a) bank learning affects loan prices, and (b) relationship benefits are heterogeneous. In particular, higher quality borrowers face differentially lower spreads as their relationship with lenders develop - and banks learn about their quality - while lower quality borrowers see loan prices increase and their loan amounts fall. We further find suggestive evidence that banks incorporate CEO-specific information into loan prices.
\end{abstract}

Keywords: learning, banks, information acquisition, relationship lending, syndicated loans.

JEL Classifications: D83, G21.

\footnotetext{
${ }^{*}$ We would like to thank the Editor, Murillo Campello, Victoria Ivashina, and an anonymous referee. We are also thankful to Vladimir Asriyan, Gabriel Chodorow-Reich, Darrell Duffie, Peter Koudijs, Xavier Freixas, Ross Levine, Doron Levit, Ulrike Malmendier, Christine Parlour, Mitchell Petersen, José Luis Peydró, Andrea Polo, Joshua Rauh, David Romer, Michel Serafinelli, Amit Seru, James Wilcox, Xiaoyu Xia, and seminar participants and discussants at Berkeley economics, Berkeley Haas, Stanford GSB, Universitat Pompeu Fabra, Santa Clara University, Wesleyan University, EconCon 2013, the EuroFIT Research Workshop on Corporate Loans 2014, the MIT Sloan Juniors in Finance Conference 2015, and the AFA Meetings in Chicago 2017 for helpful conversations and comments. We are indebted to the excellent research assistance of Christopher McConnell, Jonathan Haynes, and Mory Elsaify. The usual disclaimer applies.

${ }^{\dagger}$ Bowdoin College, email: mbotsch@bowdoin.edu

${ }^{\ddagger}$ Stanford University, email: vvanasco@stanford.edu.
} 


\section{Introduction}

Modern economies rely on well-functioning financial markets to ensure that firms can raise funds and invest in profitable projects. Informational asymmetries between borrowers and lenders can hinder the functioning of these markets, à la Akerlof (1970). Banks are one of the most important sources of external financing for firms (Gorton and Winton 2003; Degryse et al. 2015), arguably due to their special role in ameliorating informational frictions in credit markets (Diamond 1984; Boyd and Prescott 1986; Williamson 1986). In light of this, understanding the dynamics of bank information acquisition, and how this information is reflected in firms' access to and terms of credit, is central to the study of corporate finance, and more broadly, economic growth.

The banking literature has studied the role of banks as information acquirers and their importance for firms' access to credit. First, there is substantial evidence that banks obtain private borrower information both at the loan screening stage and through monitoring and servicing previously-issued loans (e.g., Mester et al. 2007; Degryse et al. 2009; Agarwal and Hauswald 2010; Norden and Weber 2010; Gustafson et al. 2016). Such "soft" or otherwise hard-to-document information can be useful for distinguishing among observationally-similar borrowers (e.g., Stein 2002, Berger et al. 2005, Liberti and Mian 2009, Rajan et al. 2015, and Darmouni 2016). Moreover, bank loan renewals are associated with positive abnormal returns to the borrower's stock price (first shown by James 1987 and Lummer and McConnell 1989), indicating the presence of private bank information. Second, there is an extensive literature that highlights the importance of firm-bank relationships for borrowers' access to credit, particularly for small and opaque borrowers (e.g., Petersen and Rajan 1994, 1995; Berger and Udell 1995; Berlin and Mester 1999; Chakraborty et al. 2010) but also for large, publicly-traded borrowers (e.g., Slovin et al. 1993; Bharath et al. 2011; Ivashina and Kovner 2011; Karolyi 2017). ${ }^{1}$ The consensus from these literatures is that lenders and borrowers both benefit from the transmission of valuable information inside a continuing relationship. ${ }^{2}$

We study bank learning from a new perspective, by investigating heterogeneity in relationship benefits across borrowers. To do so, we adapt the methodology developed by Farber and Gibbons (1996) (henceforth referred to as FG), who test for learning about worker ability in the labor market, to test

\footnotetext{
${ }^{1}$ International evidence on relationship lending includes Gibson (1997), Degryse and Van Cayseele (2000), Jiang et al. (2014), and Kysucky and Norden (2015). For reviews of this extensive literature, see Boot (2000) and Degryse et al. (2015).

${ }^{2}$ However, Boot and Thakor (1994) show that the benefits of establishing relationships are not necessarily related to learning. Relationships may also be beneficial because they reduce search frictions (Henderson and Tookes, 2012).
} 
for bank learning in credit markets. We find strong evidence that banks acquire relevant information about borrowers as relationships develop. Furthermore, banks incorporate this information into loan contracts: high quality borrowers receive lower loan rates as lending relationships progress, while lower quality borrowers see their rates unchanged or slightly increased and their loan amounts constrained. Finally, we find that part of the information that banks incorporate into loan prices is related to the CEO in place.

We test for learning using data on syndicated loans taken out by corporate borrowers. Since these borrowers are relatively large and transparent, we focus on a benchmark of market-wide learning. We accordingly define relationship time as the length of the relationship (operationalized as the number of previous packages of loans originated) between a given firm and the entire market, rather than a specific lender. In this environment, the FG methodology requires the construction of a proxy variable that is (a) correlated with a firm's creditworthiness, and (b) unobservable by banks in real time, so it cannot be used to price loans directly. We construct two such proxy variables by using out-ofsample information that reflects different aspects of firms' future, worst-case credit performance. First, we obtain each borrower's differential stock market response to a large adverse shock, the Lehman Brothers bankruptcy filing on September 15, 2008. Our strategy relies on this Stock Market Proxy containing relevant information about firms' relative performance in market-wide, left-tail events. For our second proxy, we measure each firm's worst (minimum) value of their S\&P long-term debt rating over the out-of-sample time period 2004-10. This Ratings Proxy should capture information about a firm's future, ex post creditworthiness. We then estimate loan pricing equations with relationship-timevarying coefficients on these proxies. Since our proxies are not observed by banks and cannot directly influence loan prices, an increasing loading over relationship time is evidence of banks learning about and incorporating information correlated with the proxies into subsequent loan prices.

We guarantee that our proxies are not correlated with omitted, publicly-observable firm characteristics that banks might have relied upon by orthogonalizing the proxies to the interest rate and other contract terms of the borrower's first loan in our sample. This removes any correlation between the proxy and variables used by the bank to set initial loan terms, regardless of whether we include these variables in our regressions. As a result, the orthogonalized proxies do not contain information banks used to price this first loan. This is a key insight from FG: whatever information banks used to set the terms of a borrower's first loan (which we may not observe as econometricians) is already reflected in the contract 
terms of that first loan, which we do observe, and thus, can control for. If banks do not acquire any additional information about their customers, the correlation between the orthogonalized proxy and loan terms will continue to be zero. Any non-zero correlation between the orthogonalized proxy and subsequent loan terms must reflect information banks have subsequently acquired.

We find that firms with better values of the proxy variables obtain better loan terms over relationship time. To illustrate this finding, in Figure 1 we plot average loan spreads over LIBOR against relationship time, separately for borrowers with high versus low values of the two proxies. In both panels, higher proxy values correspond to better creditworthiness. By construction, loan spreads are uncorrelated with our measures of unobserved borrower creditworthiness at relationship time zero. However, the proxies become more and more correlated with loan rates as the number of interactions with lenders in the syndicated loan market increases. This is apparent by the increasing "wedge" between rates charged to the two groups of borrowers over relationship time. In our formal econometric analysis, we show that this pattern continues to hold when controlling for relevant borrower, lender, and loan characteristics. Since the proxies cannot be observed by banks in real time, our results indicate that banks are learning about information contained in the proxies through some other source as relationships develop.

This approach additionally overcomes a common endogeneity problem. The relationship-lending literature usually estimates the relationship benefit to borrowers by estimating a loan-pricing equation augmented with some variable that measures the length, breadth, or intensity of prior lender-borrower interactions. This is equivalent to pooling all the borrowers in Figure 1 together and estimating the slope of a single price curve. But comparing longer-established relationships to shorter-established relationships runs into the issue that relationship length is endogenous. Some papers attempt to get around this problem using matching procedures (e.g., Ioannidou and Ongena, 2010) or by measuring the change in loan rates after a lending relationship terminates for exogenous reasons (e.g., Slovin et al., 1993; Darmouni, 2016). We get around this problem by comparing borrowers with the same length relationship, differing only by the value of an unobservable (to the bank) proxy variable.

We document cross-sectional heterogeneity in the division of relationship benefits that is partially consistent with hold-up theories. As first formulated by Sharpe (1990) and Rajan (1992), relationship lenders might use their private information to "hold up" borrowers and charge monopoly rents. ${ }^{3}$ The

\footnotetext{
${ }^{3}$ However, Petersen and Rajan (1995) point out that monopolistic lenders might simply be subsidizing young borrowers, who would be unable to obtain credit in competitive markets.
} 
empirical evidence is mixed, but a number of recent studies (e.g., Santos and Winton 2008, Schenone 2010, and Goel and Zemel 2015) provide support for this hypothesis. Particularly complementary to our approach, Ioannidou and Ongena (2010) find that borrowers receive a discount when switching lenders, but interest rates subsequently increase with each loan renewal. To explore these previous finding, we use our proxies to sort borrowers into high-quality vs. low-quality types. We find that the interest rate faced by low-quality borrowers stays the same or increases with each new loan, consistent with hold-up. However, the highest-quality borrowers benefit from cheaper subsequent loans. We also document cross-sectional heterogeneity in the evolution of loan amounts: we estimate that there is an increasing wedge over time between high- and low-quality borrowers for the size of credit lines.

We test for and rule out several possible violations to our identification strategy. An important concern is that the proxy variables might be capturing the influence of omitted variables that affect loan pricing but that are unrelated to bank learning. We remove the influence of all relevant relationship time-zero borrower characteristics by regressing the proxy on the time-zero interest rate, so omitted, publicly-observable borrower characteristics only pose a problem if they are both time-varying and increasingly correlated with the proxy in later years of the sample. ${ }^{4}$

To address this, we include an interaction variable between our proxy and the calendar date, and show that the interaction with relationship time is unaffected by such inclusion. This suggests that loan spreads load more on the proxies as relationships develop, independently of calendar time passing, and rules out the possibility that any correlation between the proxy and loan rates is driven solely by omitted variables that are increasingly correlated with our proxy as time passes. Another concern is the possibility of reverse causality, particularly since our proxies are constructed with data from the future. Could our results be due to low interest rates or long relationships at the end of our sample be driving better future proxy values? To shut this channel down, we include additional first-stage controls for access to credit at the time our proxies are constructed: an indicator variable for any open extensions of credit between 2006-09 and the borrower's relationship length with the syndicated loan market, measured as the total number of syndicated loans received by a firm over our sample period 1986-2003. This addresses the direct concern that variation in our proxies might be driven by firms with longer in-sample relationships enjoying better access to credit during the financial crisis (as shown

\footnotetext{
${ }^{4}$ Our methodology relies on the proxy capturing time-varying information that banks obtain through establishing lending relationships and that we do not observe. Such time-varying omitted variables are a necessity rather than a concern.
} 
in De Mitri et al. (2010) and Bolton et al. (2016)): we remove all such variation. Finally, we run a battery of additional robustness checks to dismiss other possible violations, including: unobserved time-invariant borrower characteristics, lender and match characteristics, and time-varying coefficients in the pricing equation. Our results are robust to all these different model specifications.

We find that a significant portion of bank learning is CEO-specific. When firms undergo large structural changes, such as hiring a new CEO or reorienting toward a new business model, the value of previously-acquired bank information might rapidly depreciate. Consistent with this, we find discontinuities in the learning coefficient when the firm experiences a CEO change between our sample period and the time in which we construct our Stock Market proxy. That is, proxy-relationship interactions are not as correlated with interest rates when the CEO subsequently changes. Results are similar, but weaker, when firms change industry. These findings are consistent with banks learning about certain firm characteristics, such as CEO quality, and not with reverse causality from the most recent interest rate to the future value of the proxies.

The borrowers in the syndicated loan market tend to be large and transparent, so bank learning might seem to matter less than in other commonly-studied contexts, such as small business or consumer lending. However, other recent papers have also found that asymmetric information affects important features of this marketplace, including syndicate structure (Sufi, 2007), loan spreads (Ivashina, 2009), and the use of covenants (Drucker and Puri, 2008; Murfin, 2012). Ivashina and Sun (2011) show that institutional investor participants in syndicated loan renegotiations who subsequently trade in the borrower's stock have positive abnormal returns, likely due to their access to private information. We add to this literature by showing that bank information acquisition also affects how syndicated loan contract terms evolve over time. In addition, the fact that banks appear to increasingly rely on the information they learn while lending to large, public borrowers that file detailed financial statements on a quarterly frequency reinforces the importance of financial intermediaries as delegated information acquirers in other settings.

This paper is organized as follows. In Section 2 we motivate and present our empirical strategy. In Section 3 we describe our dataset and the construction of our key variables. In Section 4 we present the main empirical results and robustness checks. In Section 5 we explore the cross-section of bank learning, and we investigate the information content of our proxies in Section 6. Section 7 concludes. 


\section{$2 \quad$ Framework for the Empirical Strategy}

\subsection{A Simple Borrower-Lender Model}

In this section we present a simple model of firm borrowing to discuss the determinants of loan agreements and the role of information in credit markets. Consider the problem of a risk-neutral bank that needs to decide whether to make a given loan, and how much to charge for it. Assume that the per-unit cost of funding for the bank is given by rate $R_{f}$. If a firm approaches a bank asking for a loan of amount $L$, the bank will compare its expected return from making that loan to its cost of funding. Let $\pi$ be the probability of the firm defaulting on the requested loan. The bank's beliefs about the firm's default probability are given by $E[\pi \mid I]$, where $I$ is the information set of the bank at the time of making the loan. The bank determines the loan interest rate, $R$, and the percentage of the loan to be collateralized $c \in[0,1]$ to ensure the loan is profitable in expectation:

$$
\begin{aligned}
(1-E[\pi \mid I]) R+E[\pi \mid I] c & \geq R_{f} \\
\Rightarrow r & \equiv R-R_{f} \geq \frac{E[\pi \mid I]}{1-E[\pi \mid I]}\left(R_{f}-c\right) \equiv \underline{\mathrm{r}} .
\end{aligned}
$$

Equation (1) determines a lower bound $\underline{r}$ for the spread $r$ that the bank can charge over its funding cost. This lower bound increases with the bank's funding cost and with the bank's expectations concerning the borrower's default probability, and it decreases with the percentage of the loan being collateralized. All of these results are standard and intuitive.

Although the determination of the actual spread, $r$, is the result of a potentially complicated bargaining process, the behavior of the lower bound is sufficient to describe our main mechanism. For the actual spread to respond to changes in the bank's information set, i.e., to bank learning, it is only necessary that some of the surplus arising from the lending contract accrue to the borrower. Importantly, this suggests that we are measuring a lower bound for learning, since the actual loan spread that we observe, $r$, might be less responsive to new information than the lower bound $\underline{r}$.

\subsection{Empirical Methodology}

Our methodology to test for bank learning is inspired by Farber and Gibbons (1996). They show that wages are increasingly predicted by a worker's Armed Forces Qualifying Test (AFQT) score as 
a worker's tenure with a firm increases. The AFQT score cannot be observed by employers, but it is presumably correlated with worker aptitude; so, this supports the idea that employers must be learning about worker quality over time. As in their paper, our methodology is designed to detect learning over time, as the relationship between banks and a firm matures. This basic methodology is well-known in labor economics but has received relatively little attention in financial economics. ${ }^{5}$

To begin, consider linearizing (1) and writing the following reduced-form pricing equation:

$$
r \approx \alpha_{0}+\alpha_{1} E[\pi \mid I]+\gamma^{\prime} w
$$

where $r$ is the loan spread and $w$ denotes the vector of other loan characteristics. Let us decompose the bank's information set about firm $f$ at time $t, I_{f, t}$ into two components: $I_{f, t}=\left\{z_{f, t}, S_{f, \tau}\right\}$, where $\tau$ measures the number of previous loans that the borrower has received (i.e., relationship length). The vector $z_{f, t}$ contains firm characteristics that are observable to all market participants at time $t$, while the vector $S_{f, \tau}=\left\{s_{f, 1}, s_{f, 2}, \ldots, s_{f, \tau}\right\}$ contains firm characteristics that are only learned when establishing lending relationships (i.e., information that banks acquire through repeated interactions with the firm, such as corporate culture, management practices, specific risk-exposures). Both $\{z, S\}$ should contain information about default probabilities that is relevant for the determination of loan prices, $r$, and other contract terms, $w$. This decomposition is illustrated in Figure 2.

As econometricians, we observe $r, w$, and $\tilde{z}$, a subset of $z$. We would like to make inference about the link from $\pi$ to $r$ due to learning by lending; that is, the path that runs through $S$ in Figure 2. Given our data, we could estimate the following linear regression:

$$
r_{l, f, t}=\alpha_{t}+\alpha_{f}+\beta^{\prime} \tilde{z}_{f, t}+\gamma^{\prime} w_{l, f, t}+\varepsilon_{l, f, t}
$$

where $l$ indexes the loan, $f$ indicates the borrowing firm, and $t$ is the origination date of the loan. The coefficient on $w$ reflects both the substitutability between other loan characteristics and interest rate spreads as well as the correlation between $w$ and $s$. Similarly, the coefficient on $\tilde{z}$ incorporates both direct and indirect pricing effects due to omitted variables.

What if we could also include the true default probability $\pi$ in the above regression? At relationship

\footnotetext{
${ }^{5}$ Iyer et al. (2015) recently use a similar methodology to test for information acquisition at the loan screening stage.
} 
time 0, even if the bank has not yet received any signals and the path through $S$ is blocked, there would be a positive loading on $\pi$ because of omitted variable bias. That is, the bank's internal model uses the full vector $z$ to forecast default probabilities, but we only include the subset $\tilde{z}$ in (3). If our learning hypothesis holds in the data, the loading on $\pi$ should increase over the course of the relationship since information $\left\{s_{f, 1}, s_{f, 2}, \ldots\right\}$ is learned by banks through lending. This observation was made by FG and is at the heart of our empirical strategy.

Of course, we cannot observe a borrower's real-world probability of default. Suppose we instead incorporate a (proxy) variable $b_{f}$ that is correlated with the borrower's probability of default $\pi$ and that is not in the bank's information set $I$ at any point in time (in Figure 2, $b$ is not directly linked to $r$ or $w)$. We expect that $b_{f}$ is unconditionally correlated with variables that we omit from our pricing equation but that banks used when pricing the first loan. To remove this dependency, we regress $b_{f}$ on the initial loan terms and on observable firm characteristics at the time $t_{0}$ when this first loan is made:

$$
b_{f}^{*}=b_{f}-E^{*}\left[b_{f} \mid \tilde{z}_{f, t_{0}}, w_{l, f, t_{0}}, r_{l, f, t_{0}}\right]
$$

and we take the residual as our proxy. Conditioning on initial loan contract terms ensures that our proxy is orthogonal to the full information set $z$ that banks used for loan pricing at the beginning of our sample. In Figure 2, the only remaining path from $b$ to $r$ is now via $S$ - the bank learning channel.

Consider adding $b_{f}^{*}$ as a regressors to (3) with a slope that is allowed to vary over relationship time $\tau$ :

$$
r_{l, f, t}=\alpha_{t}+\alpha_{f}+\beta^{\prime} \tilde{z}_{f, t}+\gamma^{\prime} w_{l, f, t}+\delta_{\tau} \cdot b_{f}^{*}+\varepsilon_{l, f, t}
$$

We are interested in studying the evolution of the coefficient $\delta_{\tau}$ calculated cross-sectionally across firms at the same relationship time $\tau$. By construction $\delta_{0}=0$. As banks receive additional signals $s_{f, \tau}$, new information becomes increasingly important in their internal forecast model $E\left[\pi_{f, t} \mid z_{f, t}, s_{f, 1}, \ldots, s_{f, \tau}\right]$. If there is learning in the data, to the extent that $b_{f}^{*}$ is correlated with these signals, the coefficient $\delta_{\tau}$ should increase in magnitude with the length of the relationship $\tau$.

The relationship-lending literature shows that having a lengthier relationship predicts improved access to credit due to private bank learning about borrower quality; however, relationship-formation is likely to be endogenous. An advantage of our methodology is that we compare borrowers with the same 
length relationships, differing only by the value of an unobservable (to the bank) proxy variable, and investigate whether these borrowers receive the same vs. different access to bank credit.

\section{Data}

\subsection{Sample Description}

We use the DealScan database on syndicated loans from Reuters LPC (April 2012 vintage) to track lender-borrower pairs ("relationships") interacting repeatedly over time. DealScan provides data for approximately 176,000 contracts comprising 248,000 syndicated loans made between 1981 and 2012, but the coverage between 1981 and 1987 is extremely limited. Each contract (or "package") can include multiple loans (or "facilities") made at the same time. A typical example is a borrower receiving both a term loan and a revolving line of credit. Syndicated loans are between a single borrower and a syndicate of lenders. One lender acts as the lead arranger and negotiates contract terms for the entire group. Most of the lenders are large commercial banks, but many syndicates include non-bank financial companies. After the contract is agreed to, a lender referred to as the Agent monitors the performance of the loan. The lead arranger and agent can be different members of the syndicate but in our final sample, they are the same in $99 \%$ of cases. Lenders playing an active role in arranging loan terms have greater opportunities to acquire borrower information than passive members of the syndicate.

We measure loan price as the all-included drawn spread, which is a composite way of reporting loan prices that can be compared across types of facilities, incorporating interest charges plus annual fees (assuming 100\% usage for lines of credit) and quoted as a spread over LIBOR. Dropping loans without an all-in drawn spread reduces the DealScan sample by one-half, to 138,000 facilities. Dropping loans originated after 2003 further reduces the sample to 72,000 facilities. Since our exercise requires access to firm financial characteristics that a bank might use to set loan rates, we obtain borrower accounting data from the Compustat Fundamentals Annual database, using the link file created by Chava and Roberts (2008). ${ }^{6}$ Restricting to linked loans reduces the sample size to 42,500, of which only 29,000 have Compustat data prior to the loan date. In order to construct market-based measures of distance to default, we require that the borrowers appear in CRSP the month prior to the deal active date, further

\footnotetext{
${ }^{6}$ We use the version of the link published on August 27, 2010, made available on Wharton Research Data Services.
} 
reducing our sample to 26,000 facilities. ${ }^{7}$ Finally, as is standard in corporate finance, we drop finance, insurance, and real estate borrowers (firms with SIC codes between 6000 \& 6999), reducing our sample to 23,594 facilities. We refer to this sample as the "public firms sample." We will use different subsets of this sample, based on availability of different proxies for future credit performance.

Each of our proxies involves a slightly different subset of the public-firms sample; the union of these proxy samples contains 8,747 packages and 12,220 facilities, involving 2,699 unique borrowers and 936 unique lead banks. The deal active dates span the years 1986 to 2003, and the average borrower takes out 4 loans in our sample. We report summary statistics about the final sample of loans and borrowers for the proxy subsamples and the all-public firms sample in Table 1. The proxy subsamples contain larger (total assets), more transparent (tangible assets, fraction with a credit rating), and less risky (higher ROA, higher Z, lower MPD) borrowers. All nominal variables are deflated using the quarterly GDP implicit price deflator to constant, year-2000 dollars.

\subsection{Measuring Relationship Time}

We follow DealScan borrower IDs to count every syndicated loan a borrower takes out over time. Since we care about the information set available to banks at the time of the agreement, we order interactions by package date (variable "deal active date") rather than by each facility's specific start date. A borrower may therefore have multiple observations at a particular moment in time. We define relationship time as the relationship length of a firm with all lenders in the syndicated market. We measure this by counting a firm's cumulative number of previous packages at a given moment in time with any lender in the market (excluding the current package). The borrowers in our setting are large and relatively transparent. Moreover, banks lend as a syndicate, so a significant component of information produced is probably shared among all the members, and possibly may be inferred by banks outside the syndicate who observe loan terms. Using Bharath et al.'s (2011) broad definition of "lead bank" that counts, on average, 1.5 lead banks per syndicate, the average borrower in our sample takes out loans with 3 distinct lead banks. This implies limited switching - on average, only two distinct syndicates per borrower. Given this, we consider firms' relationship with the market to be appropriate. ${ }^{8}$

As an example, IBM took out a package of four facilities in April 1993 for "corporate purposes," at

\footnotetext{
${ }^{7}$ We use the CRSP/Compustat Merged database to link between the two sources.

${ }^{8}$ As a robustness check, we have also measured relationship time by counting the interactions between a firm and a specific lead bank at a given moment in time. Our results are robust to both measures of relationship time.
} 
an average spread of 42 basis points over LIBOR. These four loans are the first complete observations for IBM, so we code all four as occurring at relationship time 0. Eight months later, in December 1993, IBM received a 25 basis-point-spread loan for debt repayment from a syndicate led by the same lead bank. We code this loan as occurring at relationship time 1. IBM took out additional loans in April 1994 and July 1996. Even though the lead lender in the 1996 loan did not participate in the 1994 loan, we code this package at relationship time 3. relationship times 4 and 5 refer to a revolver loan originated in February 1997 and a term loan in July 1997. In October 1998, IBM received a package of three synthetic leases for "project financing" from a new lead bank that had never previously participated in a syndicate lending to IBM. We code these three loans as occurring at relationship time 6.

Our definition of relationship time is inherently related to the average maturity of a firm's loans. A firm that typically borrows short-term and refinances more frequently will have a longer relationship length than a firm that typically borrows long-term and refinances less frequently. We do not see this as problematic. Schenone (2010) argues that "the resolution of uncertainty regarding the firm's repayment ability [...] allows the lender to accurately assess the firm's creditworthiness before granting a subsequent loan." Additionally, borrowers must produce a substantial amount of documentation every time a loan is originated or renewed. Thus, we should expect banks to learn faster about borrowers that borrow short-term and refinance more frequently. Consistent with this, Flannery (1986) describes a model in which more opaque borrowers choose to borrow at shorter maturities; and Barclay and Smith (1995) provide empirical support for this hypothesis.

Although not the primary focus of our paper, the question of how much learning is private (exclusive to the inside lender) versus public (shared among all lenders) has important policy implications for the economic value of banks and for the costs of credit crunches and bank failures. The percentage might be changing. For example, Hauswald and Marquez (2003) suggest that recent advances in information technology will allow wider dissemination of information to outside parties via spillovers, which could reduce parties' incentives to establish exclusive banking relationships. However, if information is slow to diffuse, banks might still be able to capture a fraction of informational rents, even if information is non-excludable and learning is public (e.g., Uzzi and Lancaster, 2003). This means that bank-firm relationships will remain valuable. Moreover, public learning is socially desirable. More widespread knowledge about borrower creditworthiness allows loan prices to be more finely-tuned to the specific risks involved, permitting a more efficient allocation of capital. 


\subsection{Observable Firm Characteristics}

Our model requires that we condition on the vector of financial characteristics used by the bank in setting loan prices, $z_{f, t}$. Ideally these variables would be inclusive, so we would not have to worry about correlation between omitted variables from $z_{f, t}$ and our proxy variable $b_{f}$. In our main specification, we focus on a set of variables suggested by the corporate bankruptcy literature as useful measures for predicting bankruptcy or default on debt obligations (we include additional borrower characteristics in robustness checks).

The first measure is Altman's Z score, denoted by Z. Altman (1968) investigated the determinants of corporate bankruptcy for a sample of 33 manufacturing firms that filed for bankruptcy between 19461965 and 33 firms still in existence in 1966 based on random stratified matching by industry and size. He uses discriminant analysis to estimate the following index:

$$
Z=(1.2 \cdot W C+1.4 \cdot R E+3.3 \cdot E B I T+0.6 \cdot M V E+.999 \cdot S) / A T
$$

where $\mathrm{WC}$ is working capital, RE is retained earnings, EBIT is earnings before interest and taxes, MVE is market value of equity, $\mathrm{S}$ is sales, and AT is total assets. Altman concludes that "firms having a Z score of greater than 2.99 clearly fall into the 'non-bankrupt' sector, while those firms having a Z below 1.81 are all bankrupt" (p. 606). So lower values of Z indicate an increased likelihood of bankruptcy. We Winsorize the top and bottom $0.5 \%$ of Z-score observations using the sample of all DealScan firms for which we have data over the years 1985-2012.

The second measure is Merton's probability of default, denoted by $M P D$ (which we also use for the construction of our proxy). This measure comes from the observation in Merton $(1973,1974)$ that the Black and Scholes (1973) options pricing model may also be used to calculate the market value of assets in place, by viewing the observed equity price as a call option on the unobserved market value of the entire firm. Once the market value of assets in place $V_{A}$ has been estimated, a firm's probability of default $T$ periods into the future is the probability that the value of its assets will drift below the "strike" price-the book value of liabilities. Since the Merton model assumes that $V_{A}$ follows a geometric Brownian motion with deterministic drift $\mu$ and volatility $\sigma_{A}$, this probability is given by

$$
P\left(V_{A, t+T} \leq L_{t} \mid V_{A, t}\right)=\Phi\left(-\frac{\log \left(V_{A, t} / L_{t}\right)+\left(\mu+\frac{1}{2} \sigma_{A}^{2}\right) T}{\sigma_{A} \sqrt{T}}\right) .
$$


To calculate this exact probability, one must solve the Black-Scholes equations for $V_{A}$ and $\sigma_{A}$. Rather than using a numerical solver, we use the "naïve" alternative proposed by Bharath and Shumway (2004, 2008). This naïve probability of default uses simple rules of thumb for variables in the formula above: $L_{t}$ is the book value of debt in current liabilities plus one-half the book value of long-term debt; $V_{A}$ is the sum of market value of equity plus book value of liabilities; equity volatility $\sigma_{E}$ is the annualized standard deviation of the previous year's daily stock returns; debt volatility $\sigma_{L}=.05+.25 \cdot \sigma_{E}$; and total firm volatility is the weighted sum of $\sigma_{E}$ and $\sigma_{L}$. We solve for naïve probability of default for firm $f$ at time $t, M P D_{f, t}$ for a one-year time horizon.

To ensure that both these measures were observable to lenders in real time, we lag all firm characteristics in our regressions. Market value of equity is measured on the last day of the previous month, and annualized daily equity volatility is for the twelve months prior to the current month. All fundamentals data come from the most recent annual report released at least three months prior to the month of loan origination.

\subsection{Bank Information Proxies}

A good proxy variable $b_{f}$ cannot be in the bank's information set at any time in our sample (1986-2003) and it must be correlated with a firm's future creditworthiness. Our candidates are (i) the differential response of firms to a large, negative, aggregate shock - the collapse of Lehman Brothers and the onset of the financial crisis in September 2008; and (ii) the lowest S\&P long-term debt rating held during 2004-2010. By using information about firms' performance in the out-of-sample future, we guarantee that the proxy cannot have been directly observed by banks during our sample. In what follows, we describe each proxy in detail and how they relate.

The Stock Market Proxy. We calculate the idiosyncratic component of firms' stock returns in the three months around the Lehman Brothers bankruptcy. We choose this proxy because it is likely that idiosyncratic stock returns around the Lehman filing were partially driven by firms' latent ability to deal with adverse events. If this is the case, the Stock Market Proxy contains relevant information for bank pricing. The forward-looking nature of stock market prices is well-suited to capture any new information about firm quality revealed during the financial crisis. Of course, a component of firms' stock returns during this period undoubtedly reflects housing-crisis-specific exposure; but to the extent that this 
exposure is industry-specific, we can remove this influence with industry fixed effects. We compute the cumulative abnormal return (CAR) of each firm in a $[-21,+42]$ trading-day window centered around the collapse of Lehman, starting on August 14 and ending on November 12:

$$
C A R_{f}:=\sum_{s=-21}^{+42}\left(R_{f, s}-R^{F}\right)-\hat{\beta}_{f}^{\prime}\left(R_{f a c t o r, s}\right)
$$

where $R_{f, s}$ and $R_{f a c t o r, s}$ denote the daily returns on a firm's stock and the four Fama and French (1993) - Carhart (1997) factors at time $s, R^{F}$ denotes the risk-free rate, and $s=0$ on September 15, 2008. The factor betas are estimated from time-series regressions of daily excess stock returns over 2003-2007.

The Ratings Proxy. We record the worst S\&P long-term debt rating each firm received over the years 2004-2010:

$$
\text { MinRating }_{f}:=\min \left\{\text { Rating }_{f, t}\right\}_{t=2004 m 1}^{2010 m 12}
$$

We convert the ordinal S\&P long-term debt ratings into a cardinal scale from 1 to 28 , in which an increment of \pm 3 represents a full rating change and \pm 1 a subrating (plus or minus) change: $28=$ "AAA", $25=$ "AA", $22=$ "A", ..., $4=$ "C", $3=$ "D" (Default) and $1=$ "SD" (Selective Default). ${ }^{9}$ We take the worst value observed after our sample ends to capture each borrower's worst-case ex post credit performance - in the eyes of Standard \& Poor's, how close did a given borrower come to defaulting on its debt in the seven years after our loan sample ends? As with the Stock Market Proxy, relatively lower values of the Ratings Proxy represent relatively lower-quality firms.

For both measures $b_{f} \in\left\{C A R_{f}\right.$, MinRating $\left._{f}\right\}$, we construct the final proxy, $b_{f}^{*}$, using equation (4). Time zero is the date of the first syndicated loan for each firm in our sample. Orthogonalizing against the time-zero loan characteristics removes the influence of omitted variables. This guarantees that $b_{f}^{*}$ is uncorrelated with any relevant firm characteristic the bank may have used in pricing the first loan in our sample, even if they are omitted from our pricing specification.

Banks and firms may have had relationships that preceded the firm's participation in the syndicated market. However, our procedure implicitly removes any information that banks acquired prior to the beginning of our sample period. That is, by design we zero out any learning that has previously occurred, so that we can focus on the dynamics of bank learning within our sample. To the extent that learning

\footnotetext{
${ }^{9}$ There is no "AAA-" rating, so the scale skips from 28 to 26 . Our treatment of this gap and the differing values of "SD" and "D" follows the scale assigned by Wharton Research Data Services.
} 
is diminishing over time, the inclusion of more-mature relationships will bias our estimates toward zero.

The two raw proxies are strongly correlated, with a Pearson correlation of 0.28 significant at the $1 \%$ level. We report summary statistics at the bottom of Table 1 . The mean of $C A R$ is $-9.8 \%$, indicating that the average syndicated loan borrower experienced a negative idiosyncratic return in 2008 . The mean value of MinRating is 15.5 (between BB- and BB), nearly a full-letter downgrade from the typical in-sample rating of 19 (BBB).

\section{Results}

In this section, we proceed to test whether banks learn about their borrowers as evidenced by an increasing loading on $b_{f}^{*}$ over relationship time. We discuss and rule out several alternate explanations that might explain our findings, including time-varying omitted firm-characteristics, reverse causality, firm-specific and lender-specific omitted variables, match quality, and time-varying loan pricing coefficients. Our results are consistent with the model described previously. We find robust evidence that banks learn about unobserved firm characteristics.

\subsection{Orthogonalization}

The coefficients from equation (4) for each proxy are presented in Table 2, Panel A. Note first that the all-in-spread at relationship time zero is negatively correlated with $C A R$ and MinRating, even after controlling for observable firm characteristics and other loan terms. This indicates that initial loan prices contain omitted information that is correlated in the correct direction with our proxy variables. Our bank information proxies $b_{f}^{*}$ are simply the residuals from these regression. ${ }^{10}$

We also include controls for credit access during the financial crisis and for the development of longer firm-bank relationships in-sample. This is to address the possibility of reverse causality. De Mitri et al. (2010) and Bolton et al. (2016) suggest that firms in longer relationships were less affected by the Lehman shock and had easier access to funds during the credit crunch, enabling them to better weather the shock. The specific concern is that borrowers who have developed longer relationships by the end of our sample (2003) subsequently enjoyed greater access to credit during 2008. We control for

\footnotetext{
${ }^{10}$ If the borrower received multiple loans at relationship time 0 , either due to multiple packages or multiple facilities in a single package, we include all loans in the regression. Each borrowing firm's bank information proxy is then the average of the residuals: $b_{f}^{*}=1 / L \sum_{l=1}^{L} b_{l, f}^{*}$.
} 
credit access directly, by including a dummy variable for whether a borrower had any open syndicated loans in a window around the financial crisis time period: $\mathbb{I}\{$ Access to credit between 2006-09\} $=1$ if the borrower had any open syndicated loans between January 2006 and December 2009, via either a new origination or an earlier origination that had not yet expired, and zero otherwise. We control for relationship length by including the total number of syndicated loans a borrower received between 1986-2003, in keeping with our benchmark tests for market-wide, public learning.

Our estimates indicate that access to bank credit during the financial crisis strongly predicts market performance and credit ratings: firms that received syndicated credit during 2006-09 outperformed those that did not by 4 percentage points during the Lehman time period and had a nearly one-tick higher value of MinRating between 2004-10. Interestingly, greater usage of syndicated loan credit over 1986-2003 appears to have a negative correlation with credit performance in the late 2000s. It could be that firms taking out a large number of (presumably small, short-maturity) loans are credit-constrained and cannot receive larger, longer-term loans. Or this could be a partial correlation, since we are already controlling for direct access to syndicated loan credit in 2008. Regardless, the orthogonalization procedure lets us remove the influence of both variables in all subsequent regressions.

\subsection{Baseline Learning Results}

We begin the main part of our analysis graphically. As previously shown, Figure 1 plots the all-in spread versus relationship time for high- and low-quality firms according to the two orthogonalized proxies $b_{f}^{*}$. "High-quality" firms have values of the proxy in the top third of the sample, and "low-quality" firms are in the bottom third. The negative slopes for both groups indicates an overall relationship discount: firms that have been in the market longer receive lower interest rates. This is already suggestive that borrowers benefit from establishing bank relationships, as is often found in the literature. Our contribution is to show that the interaction between relationship time and information contained in our proxies is informative for predicting loan rates: a "wedge" between high- and low-quality borrowers appears starting at relationship time 1, then widens over time. If banks were not learning about information contained in our proxies over time, the two series would always overlay each other, as they do at relationship time 0 .

Turning to a regression framework, we estimate pricing equations to assess the extent of bank learning while also controlling for time-varying firm covariates. We first report, for each proxy subsample, the 
results from estimating a standard pricing equation of the all-in drawn spread $r$ on firm characteristics $\tilde{z}$, loan characteristics $w$, and relationship time $\tau$ :

$$
r_{l, f, t}=\alpha_{t}+\alpha_{i}+\beta^{\prime} \tilde{z}_{f, t}+\gamma^{\prime} w_{l, f, t}+\varphi \cdot \tau+\varepsilon_{l, f, t}
$$

where each observation is a loan $l$ extended to firm $f$ in industry $i$ at calendar time $t$. This corresponds to equation (3) in the model except for the inclusion of relationship time. Next, we test for bank learning by adding the proxy variable $b_{f}^{*}$ to equation (10). To operationalize the time-varying coefficient in the model (equation (5)), we include the level of $b_{f}^{*}$ and its interaction with relationship time $\tau$ :

$$
r_{l, f, t}=\alpha_{t}+\alpha_{i}+\beta^{\prime} \tilde{z}_{f, t}+\gamma^{\prime} w_{l, f, t}+\delta_{0} \cdot b_{f}^{*}+\delta_{\tau} \cdot\left(b_{f}^{*} \times \tau\right)+\varphi \cdot \tau+\varepsilon_{l, f, t}
$$

By construction, the proxy variable can have no effect on loan prices at relationship time zero, so we expect $\delta_{0}$ to be zero. Our tests of bank learning focus on whether the proxy variables affect loan prices after relationship time zero - i.e., whether $\delta_{\tau}$, the coefficient on the interaction term between the proxy and relationship time, differs from zero.

Our baseline results are presented in Table 2, Panel B. We report estimates of equations (10) and (11) in subcolumns (i) and (ii), respectively, for the two proxies. Coefficients in subcolumns (i) only differ due to sample differences. We control for origination year $t$ and two-digit SIC industry $i$ fixed effects throughout the paper, and we report heteroskedasticity-robust standard errors that are clustered to allow for the presence of autocorrelation within borrower over time.

The main result from this table is that the estimates of $\delta_{\tau}$ are highly significant and take the expected signs. This corresponds to the "wedges" in Figure 1 that appear after relationship time zero and widen over time. The proxy variables are increasingly correlated with loan prices as relationship time increases. Comparing columns (i) and (ii), the inclusion of the proxies does not materially affect any of the other coefficients. This is as it should be: the proxies are orthogonalized to all loan characteristics at relationship time zero.

Interestingly, having an established presence in the syndicated loan market does not lead to lower loan prices for borrowers, controlling for firm characteristics $z$. This is reflected in the lack of significance of the relationship time coefficient $\hat{\varphi}$ in columns (1) and (2) - indeed, the coefficient is positive and 
significant in column (3), in contrast to the negative slopes apparent in Figure 1. This may be related to the construction of our proxy samples: all of the firms survive past 2003 and possibly as late as 2010 . This turns off the channel wherein banks publicly learn about borrower quality based on survivorship (older firms that survive are higher quality than non-surviving members of the same cohort). ${ }^{11}$

This might also be consistent with the "hold-up" hypothesis of Sharpe (1990) and Rajan (1992). To illustrate this, Figure 3 plots the marginal effect of relationship time on syndicated loan spreads using the estimates from Table 2, Panel B for the Stock Market Proxy (top panel) and Ratings Proxy (bottom panel). Each panel plots $\partial r / \partial \tau=\varphi+\delta_{\tau} \cdot b_{f}^{*}$ from equation (11), over the range of the orthogonalized proxy $b_{f}^{*}$. Borrowers with below-average values of the proxies (less than zero) face increasing interest rates with each loan renewal, consistent with hold-up problems, while borrowers with above-average values of the proxy (greater than zero) face decreasing interest rates. This graph emphasizes the point that relationship benefits are heterogeneous, depending on whether the bank receives positive or negative signals about a borrower's creditworthiness.

We briefly summarize the other coefficients. Higher default risk (lower Z score and higher MPD) is significantly associated with higher loan spreads. Secured loans carry a spread premium relative to unsecured loans (the omitted group is loans where the collateralization status is unreported), a seemingly counterintuitive result. This likely reflects omitted borrower characteristics: if borrowers who are required to post collateral tend to be lower quality on average, then they will also be charged higher interest rates. Larger borrowers, as measured by the log of total assets, pay lower interest rates, and revolving loans are 60 basis points cheaper than term loans. Finally, loan maturity is negatively correlated with interest rates (significant in Ratings sample).

As an illustrative example of economic significance, consider a one standard-deviation increase in the Stock Market Proxy, an increase in the CAR of 0.36 log units (approximately 36 percentage points). Holding other loan features constant, an otherwise-identical firm would benefit from a comparative reduction in its borrowing rate of $-5.291 \times 0.36=1.90$ basis points per renewal. On an average sized loan (\$336 million in constant 2000 dollars), this would result in annual savings of $\$ 64,000$ per year on the first renewal. Since the typical maturity of a loan in our sample is 3.5 years, the total savings is $\$ 224,000$. On the fourth renewal, this otherwise-identical borrower would save nearly one million dollars

\footnotetext{
${ }^{11}$ Lim et al. (2012) find only mixed evidence of a borrower-lender relationship discount in the syndicated loan market see Table IV panel A in the NBER working paper version - and Ioannidou and Ongena (2010) find a positive association between relationship time and interest rates using data from a Bolivian credit registry.
} 
in interest. Put another way, a one S.D. increase in the Stock Market Proxy has the same effect per renewal on loan prices as a 1.6 percentage point decrease in the firm's default probability. ${ }^{12}$

\subsection{Robustness Checks}

\subsubsection{Unobserved Borrower, Lender, or Relationship Heterogeneity.}

Table 3 presents a series of robustness checks for omitted, time-invariant factors. For ease of reference, we replicate the baseline results from Table 2, Panel B in the first column. FG's orthogonalization procedure should already remove the influence of any omitted, time-invariant borrower characteristics that are relevant for loan pricing. As a further check, we control for such characteristics via borrower fixed effects in column (2). The within-borrower learning coefficient is actually larger in magnitude for both proxies and retains similar levels of statistical significance. Note that the non-interacted proxy variables only vary across borrowers and thus are absorbed by the fixed effects.

Another possibility is that our results are driven by unobserved differences among lenders. For example, suppose that low cost-of-funds lenders attract high-quality borrowers. If these lenders simply offer lower interest rates on average, this would only affect the coefficient on the level of the proxy. But if these same lenders tend to offer bigger discounts over time to repeat customers, then the effect would be correlated with the interaction term between relationship time and our proxy variables. Lender fixed effects should capture any such effect, and we can reject these concerns with results from column (3).

What if some firm outcomes partly depend on the match quality with their bank? For example, Schwert (2016) finds evidence of matching in the syndicated loan market between liquidity-need firms and strongly capitalized banks. To address this concern, we directly control for borrower-lender match quality by including borrower $\times$ lender fixed effects in column (4). Within a bank-firm pair, the interaction terms between the Stock Market and Ratings proxies with relationship time remain relevant and are actually larger in magnitude than the baseline.

\footnotetext{
${ }^{12}$ Berger and Udell (1995) find pricing effects for small-business borrowers that are one order of magnitude larger: a 48 basis-point discount for a ten-year banking relationship. However, the median small-business borrower has total assets around $\$ 0.5$ million, so given the smaller loan sizes our pricing effects involve larger dollar amounts.
} 


\subsubsection{Omitted Time-Varying Public Firm Characteristics}

Although we have already ruled out lenders pricing on time-invariant borrower characteristics that are correlated with our proxies, it might be the case that lenders are observing and pricing on some public, time-varying omitted variable that is increasingly correlated with $b_{f}^{*}$ (across borrowers, within year) as time passes. What we want to rule out is the public revelation of information through standard financial reporting mechanisms that are unrelated to bank learning by lending. Since firm characteristics change over time, and since the proxy variables are taken from the future, omitted variables that are uncorrelated with $b_{f}^{*}$ at the beginning of the sample might become correlated with $b_{f}^{*}$ as time passes.

To address this possible confound, we allow the coefficient on the proxy to vary both with calendar date ( $t$, common to all borrowers) and relationship time ( $\tau$, the borrower-specific number of previous loans), as follows:

$$
r_{l, f, t}=\alpha_{t}+\alpha_{i}+\beta^{\prime} z_{f, t}+\gamma^{\prime} w_{l, f, t}+\delta_{0} b_{f}^{*}+\delta_{\tau} \cdot\left(b_{f}^{*} \times \tau\right)+\delta_{t} \cdot\left(b_{f}^{*} \times t\right)+u_{l, f, t}
$$

where $t$ is an added calendar-date time trend. If we were omitting time-varying borrower characteristics that are increasingly correlated with the proxies over time, perhaps due to the approaching future, we should observe $\delta_{t}>0$ - our proxies should be more relevant for pricing at later dates. This specification removes any correlation between the proxy and loan rates that linearly depends on the calendar date rather than relationship time. ${ }^{13}$ However, we do not find a statistically significant or economically meaningful calendar-date time trend in either of the proxy coefficients (reported in Table 4). Moreover, including this additional interaction variable barely affects the relationship-time interaction coefficient $\delta_{\tau}$, which remains a highly significant factor in the pricing equation. As an additional robustness test, we also try interacting the proxy with origination year dummy variables, allowing for any calendar-time varying trend in the correlation between the proxy and loan rates across borrowers. The coefficient on the proxy times market-time interaction variable is essentially unchanged. ${ }^{14}$

To further assess the role of omitted variables, we consider two additional tests: (1) we deliberately omit the most important time-varying characteristics from both the first- and second-stage regressions,

\footnotetext{
${ }^{13}$ The Pearson correlation between relationship time and the calendar-date time trend is 0.27 , so there is enough variation between the two for this test to be meaningful.

${ }^{14} \mathrm{We}$ also considered including borrower-specific time trends. However, the proxies interacted with relationship time are essentially borrower-specific time trends; these additional controls would absorb more than $99 \%$ of the variation in the proxy-interaction variables.
} 
and (2) we run a "kitchen-sink" style regression in which we include a bevy of additional time-varying firm-level characteristics suggested by the loan pricing literature. These results are reported in the Online Appendix. To briefly summarize, our point estimates across these various specifications are all within one standard deviation of each other, suggesting that omitted time-varying borrower characteristics are not a major concern.

\subsubsection{Placebo Proxies}

Our results present strong evidence that banks learn about and incorporate information contained in future stock market and ratings data into contemporary interest rates. Orthogonalizing the proxy variables to the time-zero interest rate on each loan removes the influence of all factors that were in banks' time-zero information set. To test how successful this orthogonalization procedure is, we also tried using a number of placebo proxies that are already in banks' time-zero information sets, because they are come from the past rather than the future. As expected, we find no evidence that banks learn about these proxies over time. These results are reported in the Online Appendix.

\subsection{The Impact of Learning on Loan Size}

Loans are multidimensional contracts, so banks could use their private information to adjust the loan's characteristics along a variety of margins. In the Online Appendix, we consider another major dimension - quantity. The dependent variable is now the log of loan size, rather than the all-in-drawn spread over LIBOR. We consider regressions on all loans in our sample, as well as broken down into the two major categories of term loans vs. revolvers. We find that higher quality borrowers do not seem to receive better access to credit via term loans, but they do seem to differentially receive larger credit lines. This result confirms previous evidence that banks grant more credit to firms that have been in the market longer.

\section{$5 \quad$ Who Benefits from Bank Learning?}

The focus of this section is to understand whether all, or only some, borrowers benefit from the surplus generated by bank learning. How should banks adjust pricing after acquiring new information about a given borrower? The answer is not straightforward, since competition in the market plays an important 
role in determining how the bank shares the relationship surplus with its borrowers. To address this question, we decompose the orthogonalized proxies into their positive and negative parts:

$$
b^{*}=b^{*+}+\left(-b^{*-}\right)
$$

where $b^{*+}:=\left|b^{*}\right| \times \mathbb{I}\left\{b^{*}>0\right\}$ and $b^{*-}:=\left|b^{*}\right| \times \mathbb{I}\left\{b^{*}<0\right\}$. We relax the implicit restriction that the coefficients on the positive and negative components are the same and estimate both the levels and the interaction variables separately. Since positive values of the proxies indicate better future creditworthiness, the coefficient on $b^{*+} \times \tau$ maps to the good-type borrowers, while that on $\left(-b^{*-}\right) \times \tau$ to the bad-type borrowers.

We report these results in Table 5. Both components are signed so that their coefficients may be interpreted as before. Since the results for both proxies are broadly similar, we focus our discussion on the Stock Market Proxy. The coefficient on good types in is -8.1, somewhat larger than the magnitude of the restricted coefficient in Table 2, Panel B, and highly significant. Conversely, the coefficient on bad types is less than half as large, -2.9 , and only marginally significant at the $10 \%$ level. The positive and significant coefficient on relationship time indicates that rates tend to rise with each loan renewal for the average borrower (possessing a proxy value near zero). However, good borrowers are priced differentially. The price of credit asymmetrically rises less rapidly, or even falls, for good borrowers more than it rises for bad borrowers as banks learn each borrower's type. In the Online Appendix, we repeat this same exercise for loan amount in place of loan price. We find that the quantity of credit asymmetrically falls more for bad borrowers than it rises for good borrowers as banks learn each borrower's type.

Overall, these results refine our understanding of the cross-sectional evolution in loan terms. As syndicated lenders acquire additional information about borrower types, they appear to back-load interest payments for most borrowers, consistent with the hold-up hypothesis of Sharpe (1990) and Rajan (1992), with only minimal price differentiation. However, very high-quality borrowers are less subject to hold-up and seem to benefit from falling loan spreads. This might be due to better firms enjoying an improved bargaining position. Very low-quality borrowers are priced the same as average-type borrowers, but they may face increasing quantity constraints over time. 


\section{Learning About What?}

In this section, we provide additional support that bank learning is the main driver of our findings. We do so by exploring our proxies: what information might be contained in these proxies that banks were learning about as much as a decade in advance? We propose and test some potential stories.

A large literature in organization economics argues that firm practices are home-grown, hard to transport, and highly persistent, even as managers change (Bloom and Van Reenen 2007, Bloom and Van Reenen 2010, Gibbons 2010). In the realm of banking, Bouwman and Malmendier (2015) find evidence of an "institutional memory" that affects decision making. On the other hand, there is growing evidence that management practices (Ichniowski et al. 1997, Black and Lynch 2001) and CEO characteristics (Bertrand and Schoar 2003, Malmendier and Tate 2005, Malmendier et al. 2011, Kaplan et al. 2012, Benmelech and Frydman 2015) can have non-negligent effects on firm value. Karolyi (2017) suggests that as much as three-quarters of the relationship benefit is CEO-specific. Motivated by this, we investigate whether our Stock Market Proxy contains information about the CEO and/or about highly-persistent firm practices.

We focus on the Stock Market Proxy because it comes from a specific date in the future. We classify loans according to whether the firm had the "same" or "different" management (the CEO, from ExecuComp) or business model (proxied for by the firm's two-digt SIC code) during the year a loan is originated and 2008, then test for the presence of a discontinuity in the learning coefficient across the two subsamples. If our proxy contains information about highly-persistent firm characteristics that are related either to the identity of managers or to the corporate business model, then we should find a smaller loading on loans that are in the "different" subsamples.

Two-digit code changes hopefully identify major shifts in a firm's business model. Firms may have some flexibility to shop for industry classifications, but this is likely to be less of a concern at the twodigit, "major-group" level. For example, IBM was primarily a hardware manufacturer in the 1990s, but when it pivoted away from hardware and into services in the early 2000s, its two-digit major group code changed to reflect this shift. CEO changes provide a useful, different source of variation from industry reclassifications; however, we can only identify CEOs' identities for the approximately one-half of our sample that appears in ExecuComp. Cross-tabulations reveal that there are many instances of firms 
that changed CEOs without changing industry classifications (reported in Table 6, Panel B). ${ }^{15}$

To implement the test, we define an indicator variable that equals 1 when the firm had a different CEO (two-digit SIC code) in the deal year vs. 2008, and 0 otherwise. We then triple-interact this variable with Proxy $\times$ RelTime to test for a discontinuity in the learning coefficient. Results are presented in Table 6, Panel A. We find that an important component of the information contained in our proxy is CEO-specific. The learning coefficient is distinctly (economically and statistically) weaker for loans taken out when firms had a different CEO than in 2008. Point estimates are broadly similar for the different-industry specifications; however the discontinuity in slopes is not statistically significant.

These results support the idea of a learning mechanism underpinning our baseline results. Furthermore, they suggest that an important component of bank learning is CEO specific: there appears to be almost no continuation of pricing on the Stock Market proxy when a different CEO is in charge.

\section{Conclusion}

In this paper we document significant heterogeneity in relationship benefits across borrowers. We adapt the methodology developed by Farber and Gibbons (1996) to study bank learning in the syndicated loan market, in order to shed new light on the dynamics of bank lending and firms' access to external finance. Consistent with the relationship-lending literature, we take seriously the proposition that lenders acquire information that allows them to better understand persistent underlying factors driving borrowers' future creditworthiness, and that they price this information into subsequent loan terms. Learning implies that relationship benefits are heterogeneous. We find that while higher quality borrowers pay differentially cheaper loan spreads as their relationship with lenders in the syndicated loan market increases - and banks learn about their quality - lower quality borrowers may see their rates increase and their loan amounts fall as they develop their relationships. Banks learn about the quality of all borrowers as relationships progress.

Despite the title of this paper, we do not mean to suggest that banks only learn by lending. Bankcustomer relationships are rich and may provide many different opportunities for information acquisition, including: securities underwriting, deposit account maintenance, and even provision of brokerage services. Moreover, our references to "banks" should not be taken too literally; finance companies, insurers,

\footnotetext{
${ }^{15}$ The CEO change measure is positively but weakly correlated with two-digit SIC changes $-\rho=0.07$.
} 
and other intermediaries that repeatedly interact with the same customer may have the opportunity to acquire and profit from information that has not previously been publicly disseminated.

Why do some borrowers receive larger relationship discounts than others? We view this as an important question for future research. We present evidence that is consistent with banks learning about the quality of management: longer relationships allow banks to better assess a firm's creditworthiness, and to price loans accordingly, when the CEO stays in place. We hope that our paper provides a first step toward a more complete understanding of the specific managerial, firm, or industry characteristics that are important for bank learning. 


\section{References}

Agarwal, S. And R. Hauswald (2010): "Distance and Private Information in Lending," Review of Financial Studies, 23, 2757-2788.

Akerlof, G. A. (1970): "The Market for "Lemons": Quality Uncertainty and the Market Mechanism," The Quarterly Journal of Economics, 84, 488-500.

Altman, E. I. (1968): "Financial Ratios, Discriminant Analysis and the Prediction of Corporate Bankruptcy," The Journal of Finance, 23, 589-609.

Barclay, M. J. And C. W. Smith (1995): "The maturity structure of corporate debt," The Journal of Finance, 50, 609-631.

Benmelech, E. and C. Frydman (2015): "Military CEOs," Journal of Financial Economics, 117, 43-59.

Berger, A. N., N. H. Miller, M. A. Petersen, R. G. Rajan, and J. C. Stein (2005): "Does Function Follow Organizational Form? Evidence from the Lending Practices of Large and Small Banks," Journal of Financial Economics, 76, 237-269.

Berger, A. N. And G. F. Udell (1995): "Relationship Lending and Lines of Credit in Small Firm Finance," Journal of Business, 68, 351-381.

Berlin, M. And L. J. Mester (1999): "Deposits and relationship lending," The Review of Financial Studies, $12,579-607$.

Bertrand, M. And A. Schoar (2003): "Managing with style: The effect of managers on firm policies," The Quarterly Journal of Economics, 118, 1169-1208.

Bharath, S. And T. Shumway (2004): "Forecasting Default with the KMV-Merton Model," AFA 2006 Boston Meetings Paper.

Bharath, S. T., S. Dahiya, A. Saunders, and A. Srinivasan (2011): "Lending relationships and loan contract terms," Review of Financial Studies, 24, 1141-1203.

Bharath, S. T. and T. Shumway (2008): "Forecasting Default with the Merton Distance to Default Model," Review of Financial Studies, 21, 1339-1369.

Black, F. And M. Scholes (1973): "The Pricing of Options and Corporate Liabilities," The Journal of Political Economy, 637-654.

Black, S. E. AND L. M. LyNCH (2001): "How to compete: the impact of workplace practices and information technology on productivity," Review of Economics and statistics, 83, 434-445.

Bloom, N. And J. VAn ReEnen (2007): "Measuring and explaining management practices across firms and countries," The Quarterly Journal of Economics, 122, 1351-1408.

- (2010): "Why do management practices differ across firms and countries?" The Journal of Economic Perspectives, 24, 203-224.

Bolton, P., X. Freixas, And L. Gambacorta (2016): "Relationship and transaction lending in a crisis," Review of Financial Studies, 2643-2676.

Bоoт, A. W. (2000): "Relationship banking: What do we know?" Journal of Financial Intermediation, 9, 7-25.

Boot, A. W. And A. V. Thakor (1994): "Moral hazard and secured lending in an infinitely repeated credit market game," International Economic Review, 899-920.

Bouwman, C. H. And U. Malmendier (2015): "Does a Bank's History Affect Its Risk-Taking?" The American Economic Review, 105, 321-325.

Boyd, J. H. And E. C. Prescott (1986): "Financial Intermediary-Coalitions," Journal of Economic Theory, $38,211-232$.

Carhart, M. (1997): "On Persistence in Mutual Fund Performance," The Journal of Finance, 52, 57-82.

Chakraborty, A., C. Fernando, and R. Mallick (2010): "The importance of being known: Relationship 
banking and credit limits," Quarterly Journal of Finance and Accounting, 27-48.

Compustat (2014): "Compustat North America Fundamentals Annual." Standard \& Poor's. Data retrieved from Wharton Research Data Services, http://wrds-web.wharton.upenn.edu/.

CRSP (2014): "Daily Stock File. Center for Research in Security Prices." Data retrieved from Wharton Research Data Services, http://wrds-web.wharton. upenn.edu/.

CRSP/Compustat Merged (2014): "CRSP/Compustat Merged Database. Center for Research in Security Prices." Data retrieved from Wharton Research Data Services, http://wrds-web. wharton. upenn.edu/.

Darmouni, O. (2016): "The Effects of Informational Frictions on Credit Reallocation," Working paper, Princeton University.

De Mitri, S., G. Gobbi, And E. Sette (2010): "Relationship Lending in a Financial Turmoil," Bank of Italy Temi di Discussione (Working Paper) No, 772.

DealScan (2012): "Thomson Reuters LPC DealScan," April 2012 vintage. Data retrieved from Wharton Research Data Services, http://wrds-web.wharton.upenn.edu/.

Degryse, H., V. IoAnnidou, And S. Ongena (2015): "Bank-firm relationships: a review of the implications for firms and banks in normal and crisis times," in The Economics of Interfirm Networks, Springer, 177-189.

Degryse, H., M. Kim, And S. Ongena (2009): Microeconometrics of banking: methods, applications, and results, Oxford University Press, USA.

Degryse, H. And P. Van Cayseele (2000): "Relationship lending within a bank-based system: Evidence from European small business data," Journal of Financial Intermediation, 9, 90-109.

Diamond, D. W. (1984): "Financial Intermediarion and Delegated Monitoring," The Review of Economic Studies, 51, 393-414.

Drucker, S. And M. Puri (2008): "On loan sales, loan contracting, and lending relationships," The Review of Financial Studies, 22, 2835-2872.

ExecuComp (2017): "Standard \& Poor's ExecuComp," Data retrieved from Wharton Research Data Services, http://wrds-web. wharton. upenn.edu/.

Fama, E. F. And K. R. French (1993): "Common Risk Factors in the Returns on Stocks and Bonds," Journal of Financial Economics, 33, 3-56.

Farber, H. S. And R. Gibbons (1996): "Learning and Wage Dynamics," Quaterly Journal of Economics, 111, 1007-1047.

Flannery, M. J. (1986): "Asymmetric information and risky debt maturity choice," The Journal of Finance, $41,19-37$.

Gibbons, R. (2010): "Inside organizations: Pricing, politics, and path dependence," Annu. Rev. Econ., 2, 337365.

GiBson, M. S. (1997): "More Evidence on the Link Between Bank Health and Investment in Japan," Journal of the Japanese And International Economies, 11, 296-310.

Goel, M. And M. Zemel (2015): "Friendship Matters Less on a Rainy Day: Firm Outcomes and Relationship Bank Health," Working paper.

Gorton, G. And A. Winton (2003): "Financial intermediation," Handbook of the Economics of Finance, 1, $431-552$.

Gustafson, M., I. Ivanov, And R. Meisenzahk (2016): "Bank Monitoring: Evidence from Syndicated Loans," Working paper.

Hauswald, R. and R. Marquez (2003): "Information Technology and Financial Services Competition," The Review of Financial Studies, 16, 921-948.

Henderson, B. J. And H. Tookes (2012): "Do investment banks' relationships with investors impact pricing? The case of convertible bond issues," Management Science, 58, 2272-2291. 
Ichniowski, C., K. Shaw, And G. Prennushi (1997): "The effects of human resource management practices on productivity: A study of steel finishing lines," The American Economic Review, 291-313.

IoANnidou, V. AND S. Ongena (2010): "Time for a change: loan conditions and bank behavior when firms switch banks," The Journal of Finance, 65, 1847-1877.

Ivashina, V. (2009): "Asymmetric information effects on loan spreads," Journal of Financial Economics, 92, $300-319$.

Ivashina, V. AND A. Kovner (2011): "The private equity advantage: Leveraged buyout firms and relationship banking," The Review of Financial Studies, 24, 2462-2498.

IVASHINA, V. AND Z. SUn (2011): "Institutional stock trading on loan market information," Journal of Financial Economics, 100, 284-303.

Iyer, R., A. I. Khwaja, E. F. Luttmer, And K. Shue (2015): "Screening peers softly: Inferring the quality of small borrowers," Management Science, 62, 1554-1577.

James, C. (1987): "Some evidence on the uniqueness of bank loans," Journal of Financial Economics, 19, 217 235.

JiAnG, J., Z. LI, AND C. Lin (2014): "Financing Difficulties of SMEs from Its Financing Source in China," Journal of Service Science and Management, 196-200.

Kaplan, S. N., M. M. Klebanov, and M. Sorensen (2012): "Which CEO characteristics and abilities matter?" The Journal of Finance, 67, 973-1007.

Karolyi, S. A. (2017): "Personal Lending Relationships," forthocoming at The Journal of Finance.

Kysucky, V. AND L. NoRden (2015): "The benefits of relationship lending in a cross-country context: A meta-analysis," Management Science, 62, 90-110.

Liberti, J. M. And A. R. Mian (2009): "Estimating the Effect of Hierarchies on Information Use," Review of Financial Studies, 22, 4057-4090.

Lim, J., B. A. Minton, And M. Weisbach (2012): "Syndicated Loan Spreads and the Composition of the Syndicate," NBER Working Paper 18356.

Lummer, S. L. AND J. J. MCConnell (1989): "Further evidence on the bank lending process and the capitalmarket response to bank loan agreements," Journal of Financial Economics, 25, 99-122.

Malmendier, U. and G. TATE (2005): "CEO overconfidence and corporate investment," The journal of finance, $60,2661-2700$.

Malmendier, U., G. TAte, and J. Yan (2011): "Overconfidence and early-life experiences: the effect of managerial traits on corporate financial policies," The Journal of finance, 66, 1687-1733.

Merton, R. (1973): "Theory of Rational Option Pricing," The Bell Journal of Economics and Management, 4, $141-183$.

Merton, R. C. (1974): "On the Pricing of Corporate Debt: The Risk Structure of Interest Rates," The Journal of Finance, 29, 449-470.

Mester, L. J., L. I. Nakamura, and M. Renault (2007): "Transactions accounts and loan monitoring," Review of Financial Studies, 20, 529-556.

Murfin, J. (2012): "The supply-side determinants of loan contract strictness," The Journal of Finance, 67, $1565-1601$.

Norden, L. And M. Weber (2010): "Credit line usage, checking account activity, and default risk of bank borrowers," Review of Financial Studies, 23, 3665-3699.

Petersen, M. A. And R. G. Rajan (1994): "The benefits of lending relationships: Evidence from small business data," The journal of finance, 49, 3-37.

(1995): "The Effect of Credit Market Competition on Lending Relationships," Quaterly Journal of Economics, 110, 407-443. 
RAJAN, R. G. (1992): "Insiders and Outsiders: The Choice between Informed and Arm's-Length Debt," The Journal of Finance, 47, 1367-1400.

Rajan, U., A. SERu, AND V. Vig (2015): "The failure of models that predict failure: Distance, incentives, and defaults," Journal of Financial Economics, 115, 237 - 260.

Santos, J. A. And A. Winton (2008): "Bank loans, bonds, and information monopolies across the business cycle," The Journal of Finance, 63, 1315-1359.

Schenone, C. (2010): "Lending Relationships and Information Rents: Do Banks Exploit Their Information Advantages?" The Review of Financial Studies, 23, 1149-1199.

Schwert, M. (2016): "Bank Capital and Lending Relationships," Working paper.

Sharpe, S. (1990): "Asymmetric Information, Bank Lending, and Implicit Contracts: A Stylized Model of Customer Relationships," The Journal of Finance, 45, 1069-87.

Slovin, M. B., M. E. Sushka, And J. A. Polonchek (1993): "The Value of Bank Durability: Borrowers as Bank Stakeholders," The Journal of Finance, 48, 247-266.

S\&P (2014): "Standard \& Poor's Credit Ratings," Data retrieved from Wharton Research Data Services, http: //wrds-web. wharton. upenn.edu/.

Stein, J. (2002): "Information Production and Capital Allocation: Decentralized versus Hierarchical Firms," The Journal of Finance, 57, 1891-1921.

Sufi, A. (2007): "Information asymmetry and financing arrangements: Evidence from syndicated loans," The Journal of Finance, 62, 629-668.

Uzzi, B. And R. LAncaster (2003): "Relational embeddedness and learning: The case of bank loan managers and their clients," Management Science, 49, 383-399.

Williamson, S. D. (1986): "Costly monitoring, financial intermediation, and equilibrium credit rationing," Journal of Monetary Economics, 18, 159-179. 


\section{Figure 1. Loans are Increasingly Priced on the Proxies}
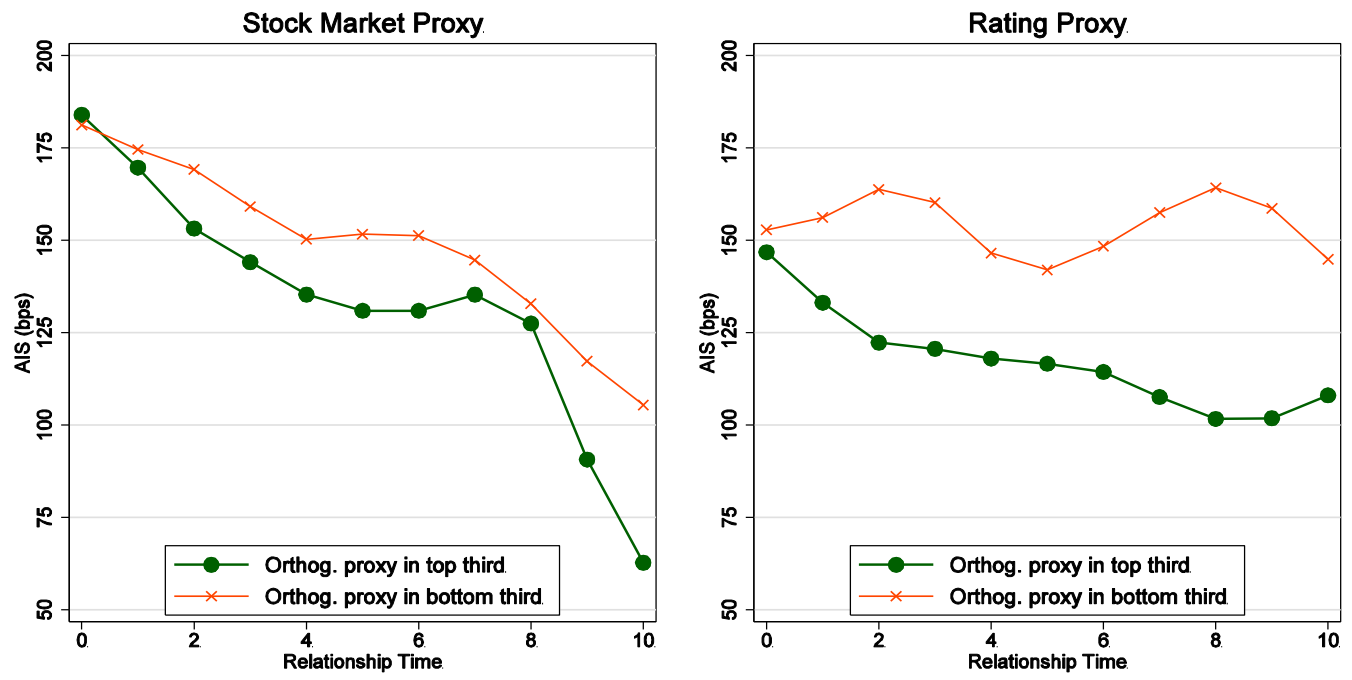

This figure shows the average all-in drawn spread (AIS) over LIBOR paid by syndicated loan borrowers with top-third (high creditworthiness) versus bottom-third (low creditworthiness) values of the orthognalized proxies. The series are smoothed using a moving average, $[-1,+1]$ triangular filter.

Notes.

1. Relationship Time is the number of loans a borrower has received from lenders in the syndicated loan market in the past.

2. The Stock Market Proxy is a borrower's [-21,+42]-day cumulative AR around 9/15/2008, orthogonalized to Relationship Time 0 borrower and loan characteristics.

3. The Ratings Proxy is a borrower's worst S\&P long-term debt rating over 2004-10, orthogonalized to Relationship Time 0 borrower and loan characteristics. 
Figure 2. Overview of the Information Structure

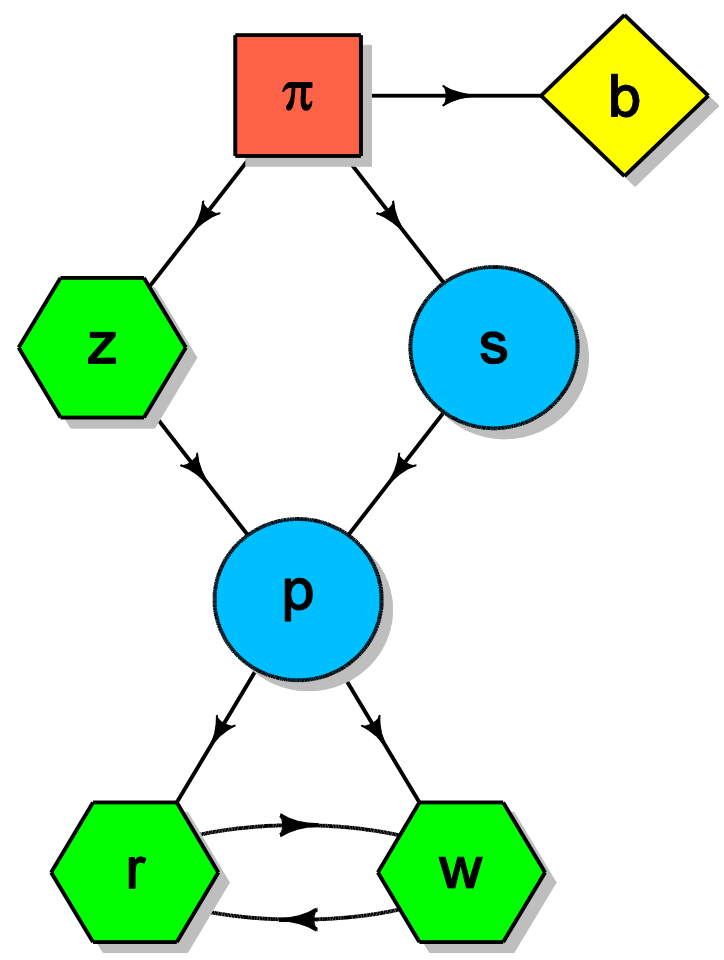

This diagram shows how banks uses their information set $(\mathbf{z}, \mathbf{s})$ to form a prediction of the borower's default probability, $\mathbf{p}=\mathbf{E}[\boldsymbol{\pi} \mid \mathbf{z}, \mathbf{s}]$, and set loan contract terms $(\mathbf{r}, \mathbf{w})$. Arrows indicate correlations between connected variables.

\section{Legend:}

Circles variables that only the bank sees.

Diamonds variables that only we see, and not the bank.

Hexagons variables that we observe along with the bank.

Squares variables that no one sees. 


\section{Figure 3. Coefficients on Relationship Time in the Baseline Learning Specification}
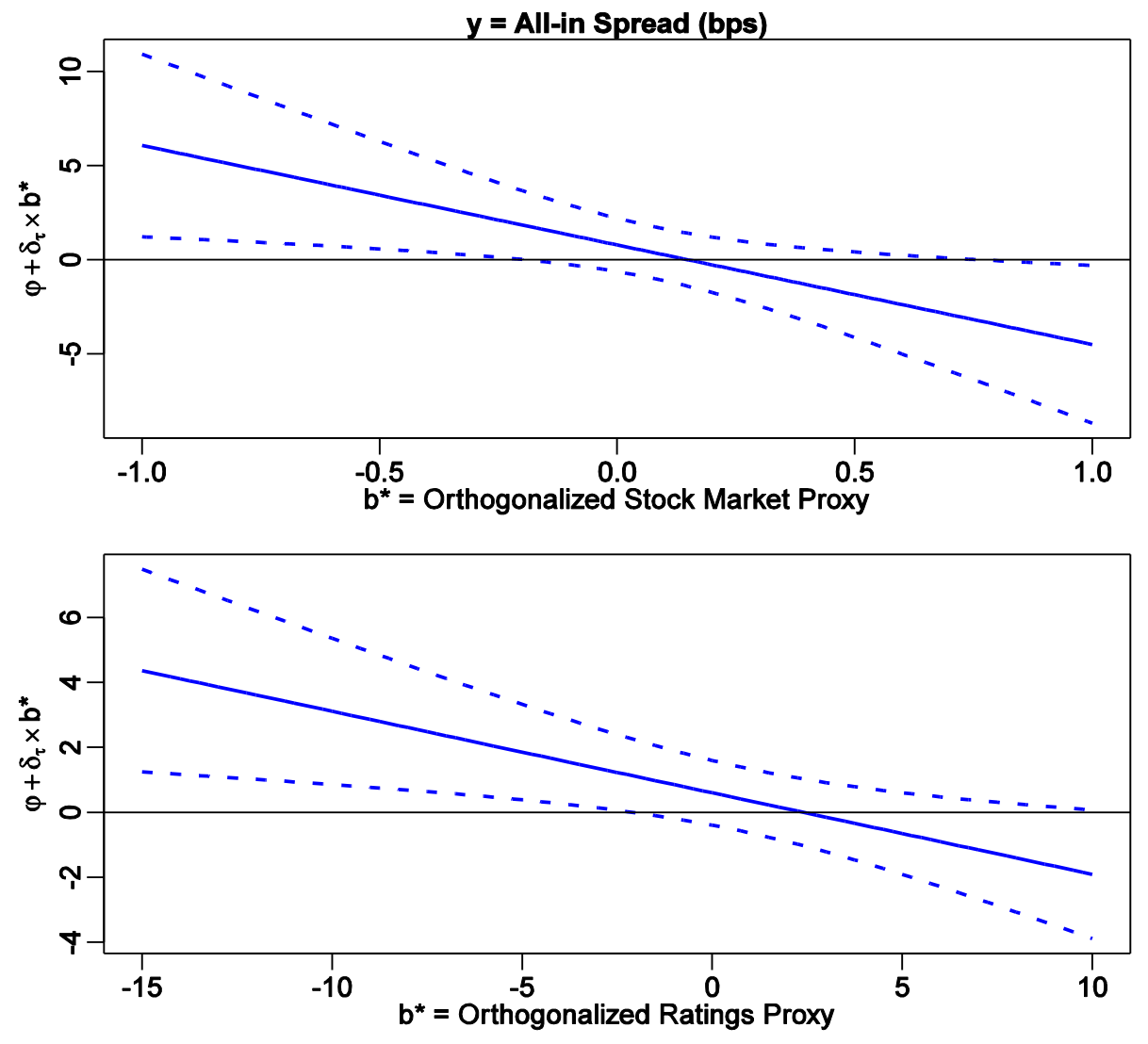

Notes.

All coefficients and 2-SE bands are from Table 2, Panel B, Column (2)

1. Relationship Time is the number of loans a borrower has received from lenders in the syndicated loan market in the past.

2. The Stock Market Proxy is a borrower's [-21,+42]-day cumulative AR around 9/15/2008, orthogonalized to Relationship Time 0 borrower and loan characteristics.

3. The Ratings Proxy is a borrower's worst S\&P long-term debt rating over 2004-10, orthogonalized to Relationship Time 0 borrower and loan characteristics. 


\section{Table 1: Summary Statistics}

This table reports summary statistics for syndicated loan facilities originated between 1987 and 2003. First column reports summary statistics on subsamples of borrowers for which one of the two proxies is available: "Stock Market Proxy" firms were publicly-traded in 2008 and "Ratings Proxy" firms had at least one S\&P long-term debt rating between 2004-10. The second column reports summary statistics for the "All Public Firms" sample of LPC Dealscan facilities to borrowers appearing in the Compustat-CRSP Merged database, using the Chava and Roberts (2008) link file, for which loan terms are available. All differences in third column are significant at a $5 \%$ level.

\begin{tabular}{|c|c|c|c|}
\hline Panel A: Facility Characteristics & $\begin{array}{c}\text { Proxy Subsamples } \\
\mathrm{N}=12,220\end{array}$ & $\begin{array}{l}\text { All public firms } \\
\qquad N=\mathbf{2 3 , 5 9 4}\end{array}$ & \\
\hline & Mean (SD) & Mean (SD) & Difference \\
\hline All-in spread (bps) & $\begin{array}{c}158.2 \\
(127.37)\end{array}$ & $\begin{array}{c}196.9 \\
(140.11)\end{array}$ & -38.6 \\
\hline Loan Size (constant 2000 \$m) & $\begin{array}{c}380.5 \\
(877.83)\end{array}$ & $\begin{array}{c}265.3 \\
(722.38)\end{array}$ & 115.2 \\
\hline Maturity (months) & $\begin{array}{c}42.5 \\
(28.54)\end{array}$ & $\begin{array}{c}42.3 \\
(28.40)\end{array}$ & 0.2 \\
\hline Fraction revolver & $\begin{array}{l}0.733 \\
(0.44)\end{array}$ & $\begin{array}{l}0.711 \\
(0.45)\end{array}$ & 0.023 \\
\hline Fraction collateralized & $\begin{array}{l}0.393 \\
(0.49)\end{array}$ & $\begin{array}{l}0.504 \\
(0.50)\end{array}$ & -0.111 \\
\hline Fraction not collateralized & $\begin{array}{l}0.188 \\
(0.39)\end{array}$ & $\begin{array}{l}0.141 \\
(0.35)\end{array}$ & 0.046 \\
\hline Syndicate size & $\begin{array}{c}9.2 \\
(10.2)\end{array}$ & $\begin{array}{c}7.1 \\
(9.2)\end{array}$ & 2.1 \\
\hline Fraction relationship loans [1] & $\begin{array}{l}0.571 \\
(0.49)\end{array}$ & $\begin{array}{l}0.544 \\
(0.50)\end{array}$ & 0.027 \\
\hline Panel B: Borrowing Firm Characteristics & $\begin{array}{c}\text { Proxy Subsamples } \\
\mathrm{N}=\mathbf{8 , 4 1 9}\end{array}$ & $\begin{array}{c}\text { Public Sample } \\
\qquad=16,133\end{array}$ & \\
\hline & Mean (SD) & Mean (SD) & Difference \\
\hline Total assets (constant $2000 \$ b)$ & $\begin{array}{l}6.75 \\
(22.0)\end{array}$ & $\begin{array}{l}4.11 \\
(16.4)\end{array}$ & 2.63 \\
\hline Tangible assets ( $\%$ of total) & $\begin{array}{l}37.9 \\
(24.0)\end{array}$ & $\begin{array}{l}34.8 \\
(23.8)\end{array}$ & 3.1 \\
\hline Fraction with $\mathrm{LT}$ debt rating from S\&P & $\begin{array}{l}0.58 \\
(0.5)\end{array}$ & $\begin{array}{l}0.42 \\
(0.5)\end{array}$ & 0.16 \\
\hline Average Q [2] & $\begin{array}{c}1.48 \\
(1.45)\end{array}$ & $\begin{array}{c}1.44 \\
(1.48)\end{array}$ & 0.04 \\
\hline ROA (\%) & $\begin{array}{c}3.11 \\
(10.88)\end{array}$ & $\begin{array}{c}0.72 \\
(15.51)\end{array}$ & 2.39 \\
\hline Z score & $\begin{array}{l}2.51 \\
(1.68)\end{array}$ & $\begin{array}{l}2.44 \\
(1.82)\end{array}$ & 0.07 \\
\hline Merton Probability of Default ( $\% / 100)$ & $\begin{array}{l}0.078 \\
(0.22)\end{array}$ & $\begin{array}{l}0.105 \\
(0.25)\end{array}$ & -0.026 \\
\hline \multicolumn{4}{|l|}{ Proxies } \\
\hline CAR $(\% / 100)[3]$ & $\begin{array}{l}-0.098 \\
(0.36)\end{array}$ & N.A. & \\
\hline $\begin{array}{l}\text { MinRating , 2004-10 [4] } \\
\quad(1=\mathrm{D}, 4=\mathrm{C}, 7=\mathrm{CC}, \ldots, 28=\mathrm{AAA})\end{array}$ & $\begin{array}{l}15.52 \\
(4.79)\end{array}$ & N.A. & \\
\hline
\end{tabular}

Notes.

In Panel A, each observation is a facility; in Panel B, a borrower-month.

[1] Relationship Loan $=1$ if the borrower has received credit from the same lead bank at least once in the previous five years; 0 if the borrower has received credit in the previous five years, but only from different lead banks; and is not classified if the borrower has not received credit in the previous five years. Lead banks are identified using the Bharath et al. (2011) definition. 2,822 (7,027) facilities are not classified in the Proxy (Public) Samples.

[2] $\mathrm{Q}=(\mathrm{E}+\mathrm{P}+\mathrm{D}) / \mathrm{A}$, where $\mathrm{E}$ is market value of common equity, $\mathrm{P}$ is liquidating value of preferred stock, $\mathrm{D}$ is book value of long-term debt plus current liabilities net of (current assets less inventories), and A is book value of total assets.

[3] $\boldsymbol{C A R}$ is the [-21,+42]-day Fama-French-Carhart CAR, centered on 9/15/2008 (\%/ 100).

[4] MinRating is the worst S\&P long-term debt rating received over 2004-10. Increments of +3 indicate full-letter upgrades. 


\section{Table 2. Do Banks Learn by Lending?}

This table reports tests of bank learning by lending. Panel A reports the first-stage, across-borrower regressions of each proxy variable for borrower creditworthiness on market-time 0 loan and firm characteristics. The residuals from these regressions are the "orthogonalized proxies" in the second stage. Panel B reports second-stage panel regressions of loan spreads over LIBOR on each orthogonalized proxy and its interaction with Relationship Time (the number of previous syndicated loans a borrower has received). The sample is LPC Dealscan facilities originated between 1986 and 2003 to borrowers appearing in the Compustat-CRSP Merged database, for whom loan terms and each proxy is available.

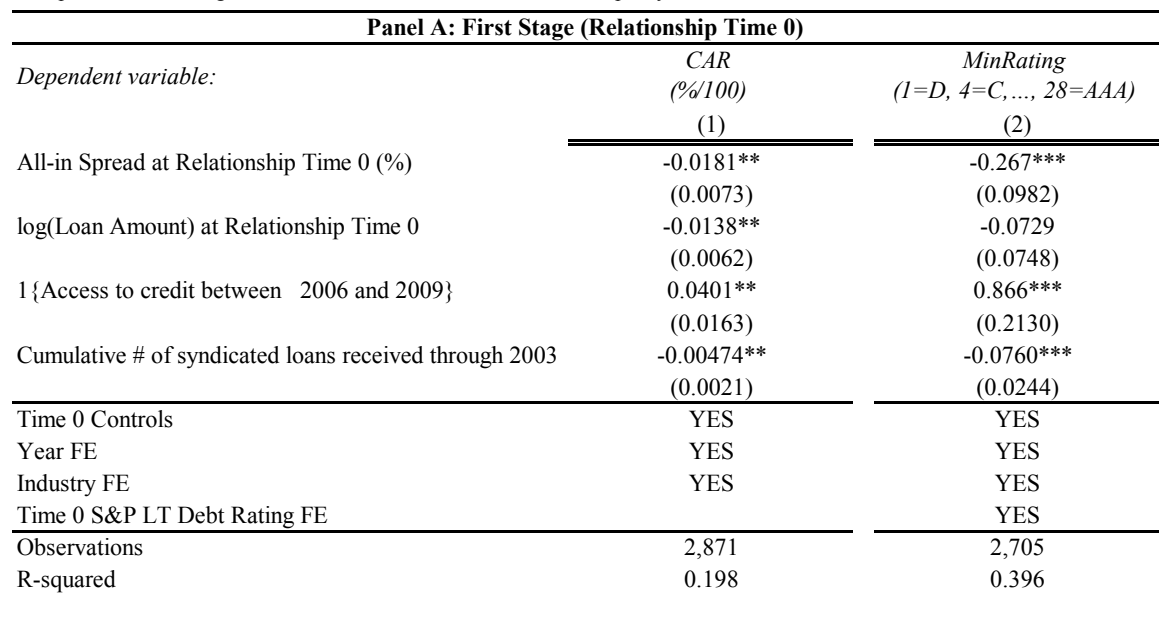

\begin{tabular}{|c|c|c|c|c|}
\hline \multicolumn{5}{|c|}{ Panel B: Second Stage (all loans) } \\
\hline \multirow[t]{3}{*}{ Dependent variable: } & \multicolumn{4}{|c|}{ Interest Rate spread over LIBOR (in bps) } \\
\hline & \multicolumn{2}{|c|}{ Stock Market Proxy } & \multicolumn{2}{|c|}{ Ratings Proxy } \\
\hline & $(1)$ & $(2)$ & (3) & $(4)$ \\
\hline Relationship Time & $\begin{array}{l}0.71 \\
(0.74)\end{array}$ & $\begin{array}{c}0.78 \\
(0.71)\end{array}$ & $\begin{array}{l}0.51 \\
(0.50)\end{array}$ & $\begin{array}{l}0.60 \\
(0.50)\end{array}$ \\
\hline Orthogonalized Proxy $\times$ Relationship Time & & $\begin{array}{c}-5.291 * * \\
(2.16)\end{array}$ & & $\begin{array}{c}-0.251 * * * \\
(0.09)\end{array}$ \\
\hline Orthogonalized Proxy & & $\begin{array}{c}7.57 \\
(6.02)\end{array}$ & & $\begin{array}{c}-0.34 \\
(0.46)\end{array}$ \\
\hline Borrower's Z score & $\begin{array}{c}-12.87 * * * \\
(1.05)\end{array}$ & $\begin{array}{c}-12.84 * * * \\
(1.05)\end{array}$ & $\begin{array}{c}-8.706^{* * * *} \\
(1.10)\end{array}$ & $\begin{array}{c}-8.423 * * * \\
(1.11)\end{array}$ \\
\hline Merton Probability of Default $(\% / 100)$ & $\begin{array}{c}117.6^{* * *} \\
(10.91)\end{array}$ & $\begin{array}{c}117.8 \text { *** } \\
(10.74)\end{array}$ & $\begin{array}{c}63.45^{* * * *} \\
(8.38)\end{array}$ & $\begin{array}{c}62.11 * * * \\
(8.36)\end{array}$ \\
\hline $\log$ (Total Assets) & $\begin{array}{c}-24.76^{* * *} \\
(1.09)\end{array}$ & $\begin{array}{c}-24.91 * * * \\
(1.09)\end{array}$ & $\begin{array}{c}-15.88^{* * *} \\
(1.35)\end{array}$ & $\begin{array}{c}-16.28 * * * \\
(1.34)\end{array}$ \\
\hline $1\{$ loan is secured $\}$ & $\begin{array}{c}66.14^{* * * *} \\
(4.00)\end{array}$ & $\begin{array}{c}65.52 * * * \\
(3.97)\end{array}$ & $\begin{array}{c}58.42 * * * \\
(3.90)\end{array}$ & $\begin{array}{c}58.00^{* * *} \\
(3.91)\end{array}$ \\
\hline $1\{$ loan is not secured $\}$ & $\begin{array}{c}-13.05 * * * \\
(2.84)\end{array}$ & $\begin{array}{c}-13.11 \text { *** } \\
(2.81)\end{array}$ & $\begin{array}{c}-8.107 * * * \\
(2.47)\end{array}$ & $\begin{array}{c}-7.729 * * * \\
(2.46)\end{array}$ \\
\hline Loan Maturity (months) & $\begin{array}{r}-0.0243 \\
(0.051)\end{array}$ & $\begin{array}{c}-0.0240 \\
(0.051)\end{array}$ & $\begin{array}{c}-0.0947 * * \\
(0.048)\end{array}$ & $\begin{array}{c}-0.0905 * \\
(0.048)\end{array}$ \\
\hline 1 \{revolver loan\} & $\begin{array}{c}-58.18 * * * \\
(3.56)\end{array}$ & $\begin{array}{c}-58.24 * * * \\
(3.51)\end{array}$ & $\begin{array}{c}-60.66 * * * \\
(3.11)\end{array}$ & $\begin{array}{c}-60.71 * * * \\
(3.11)\end{array}$ \\
\hline Year FE & YES & YES & YES & YES \\
\hline Industry FE & YES & YES & YES & YES \\
\hline S\&P LT Debt Rating FE & & & YES & YES \\
\hline Observations & 8,673 & 8,673 & 9,458 & 9,458 \\
\hline R-squared & 0.551 & 0.553 & 0.594 & 0.595 \\
\hline
\end{tabular}

Standard errors clustered by borrower in parentheses.

$* * * \mathrm{p}<0.01, * * \mathrm{p}<0.05, * \mathrm{p}<0.1$

Notes.

1. $\boldsymbol{C A R}$ is the $[-21,+42]$-day Fama-French-Carhart CAR, centered on 9/15/2008.

2. MinRating is the worst S\&P long-term debt rating received over 2004-10. Increments of +3 indicate full-letter upgrades.

3. Relationship Time is the number of loans a borrower has received from lenders in the syndicated loan market in the past.

4. 1 Access to credit between 2006 and 2009$\}=$ dummy variable for whether borrower had any open syndicated loans during financial crisis period (expiration date after Dec. 2005 and start date before Jan. 2010).

5. Time 0 controls are: firm's Z-score, MPD, and $\log$ (assets) at time $0+$ collateral status, maturity, and revolver dummy for first syndicated loan in sample.

6. For secured and unsecured dummies, the omitted category is "not reported" (approximately one-third of loans). 


\section{Table 3: Fixed Effect Regressions}

This table reports fixed-effect regressions of syndicated loan interest rates on orthogonalized proxies for borrower creditworthiness. The sample is LPC Dealscan facilities originated between 1986 and 2003 to borrowers appearing in the Compustat-CRSP Merged database, for whom loan terms and each proxy is available.

\begin{tabular}{|c|c|c|c|c|}
\hline \multirow[t]{3}{*}{ Dependent variable: } & \multicolumn{4}{|c|}{ Interest Rate spread over LIBOR (in bps). } \\
\hline & \multicolumn{4}{|c|}{ A. Stock Market Proxy } \\
\hline & (1) & (2) & (3) & (4) \\
\hline \multirow[t]{2}{*}{ Relationship Time } & 0.783 & $3.085 * * *$ & $0.989^{*}$ & 0.188 \\
\hline & $(0.71)$ & $(1.10)$ & $(0.55)$ & $(1.18)$ \\
\hline \multirow[t]{2}{*}{ Stock Market Proxy $\times$ Relationship Time } & $-5.291 * *$ & $-6.081 * *$ & $-4.371 * *$ & $-6.288^{* *}$ \\
\hline & $(2.15)$ & $(2.63)$ & $(1.86)$ & $(2.57)$ \\
\hline \multirow[t]{2}{*}{ Stock Market Proxy } & 7.57 & Absorbed & 3.827 & Absorbed \\
\hline & $(6.02)$ & by $F E$ & $(5.23)$ & by $F E$ \\
\hline Number of facilities & 8,673 & 8,673 & 8,614 & 8,614 \\
\hline \multirow[t]{3}{*}{ R-squared } & 0.55 & 0.79 & 0.67 & 0.92 \\
\hline & \multicolumn{4}{|c|}{ B. Ratings Proxy } \\
\hline & $(1)$ & $(2)$ & $(3)$ & $(4)$ \\
\hline \multirow[t]{2}{*}{ Relationship Time } & 0.634 & 1.500 & $0.577^{* *}$ & $-2.573^{* *}$ \\
\hline & $(0.59)$ & $(1.17)$ & $(0.28)$ & $(1.30)$ \\
\hline \multirow[t]{2}{*}{ Ratings Proxy $\times$ Relationship Time } & $-0.253 * * *$ & $-0.589 * * *$ & $-0.232 * * *$ & $-0.554 * * *$ \\
\hline & $(0.09)$ & $(0.14)$ & $(0.05)$ & $(0.17)$ \\
\hline \multirow[t]{2}{*}{ Ratings Proxy } & -0.329 & Absorbed & -0.17 & Absorbed \\
\hline & $(0.46)$ & by $F E$ & $(0.35)$ & by $F E$ \\
\hline Number of facilities & 9,458 & 9,458 & 9,386 & 9,386 \\
\hline R-squared & 0.595 & 0.774 & 0.667 & 0.904 \\
\hline Control Variables & YES & YES & YES & YES \\
\hline Year FE & YES & YES & YES & YES \\
\hline Industry FE & YES & & & \\
\hline Borrower FE & & YES & & YES \\
\hline Lender FE & & & YES & YES \\
\hline Borrower $\times$ Lender FE & & & & YES \\
\hline
\end{tabular}

Standard errors clustered by borrower (cols. 1-2), lender (col. 3) and both (col. 4) in parentheses.

$* * * \mathrm{p}<0.01, * * \mathrm{p}<0.05, * \mathrm{p}<0.1$

Notes.

1. Column 1 reproduces the baseline learning specifications from Table 2 Panel B (columns 2 and 4).

2. The Stock Market Proxy is a borrower's [-21,+42]-day cumulative AR around 9/15/2008, orthogonalized to Relationship Time 0 borrower and loan characteristics.

3. The Ratings Proxy is a borrower's worst S\&P long-term debt rating over 2004-10, orthogonalized to Relationship Time 0 borrower and loan characteristics.

4. Relationship Time is the number of loans a borrower has received from lenders in the syndicated loan market in the past.

5. Control variables are: $\mathrm{Z}$ score, default probability, $\log$ (assets), secured and revolver indicators, and loan maturity. Panel B additionally includes S\&P LT debt rating fixed effects.

6. We include lender and borrower $\times$ lender fixed effects in columns 3 and 4 by running WLS on a lead-bank $\times$ firm panel dataset, with each loan's characteristics replicated across all lead bank members of the syndicate. The weights are inversely proportional to the number of replicate observations, so that every facility receives equal weight. These specifications omit facilities for which we cannot identify a lead bank using Bharath et al.'s (2011) definition. 


\section{Table 4: Time Trend Specifications}

This table reports OLS regressions of syndicated loan interest rates on orthogonalized proxies for borrower creditworthiness, interacted both with "Relationship Time" (the cumulative number of previous loans) and a calendar-date time trend. The sample is LPC Dealscan facilities originated between 1986 and 2003 to borrowers appearing in the Compustat-CRSP Merged database, for whom loan terms and each proxy is available.

\begin{tabular}{|c|c|c|c|c|}
\hline \multirow[t]{3}{*}{ Dependent variable: } & \multicolumn{4}{|c|}{ Interest Rate spread over LIBOR (in bps) } \\
\hline & \multicolumn{2}{|c|}{ Stock Market Proxy } & \multicolumn{2}{|c|}{ Ratings Proxy } \\
\hline & $(1)$ & $(2)$ & $(3)$ & $(4)$ \\
\hline \multirow[t]{2}{*}{ Relationship Time } & 0.783 & 0.784 & 0.596 & 0.622 \\
\hline & $(0.710)$ & $(0.708)$ & $(0.499)$ & $(0.500)$ \\
\hline \multirow[t]{2}{*}{ Proxy $\times$ Relationship Time } & $-5.320 * *$ & $-5.307 * *$ & $-0.211 * *$ & $-0.212 * *$ \\
\hline & $(2.243)$ & $(2.236)$ & $(0.100)$ & $(0.099)$ \\
\hline \multirow[t]{2}{*}{ Proxy } & 7.502 & Absorbed & -0.286 & Absorbed \\
\hline & $(5.988)$ & by $F E$ & $(0.464)$ & by $F E$ \\
\hline \multirow[t]{2}{*}{ Proxy $\times$ Time Trend } & 0.0837 & & -0.118 & \\
\hline & $(1.168)$ & & $(0.106)$ & \\
\hline Control variables & YES & YES & YES & YES \\
\hline Year FE & YES & YES & YES & YES \\
\hline Industry FE & YES & YES & YES & YES \\
\hline Proxy $\times$ Year FE & & YES & & YES \\
\hline S\&P LT Debt Rating FE & & & YES & YES \\
\hline Observations & 8,673 & 8,673 & 9,458 & 9,458 \\
\hline R-squared & 0.553 & 0.553 & 0.595 & 0.595 \\
\hline
\end{tabular}

Standard errors clustered by borrower in parentheses.

$* * * \mathrm{p}<0.01, * * \mathrm{p}<0.05, * \mathrm{p}<0.1$

Notes.

1. The Stock Market Proxy is a borrower's [-21,+42]-day cumulative AR around 9/15/2008, orthogonalized to Relationship Time 0 borrower and loan characteristics.

2. The Ratings Proxy is a borrower's worst S\&P long-term debt rating over 2004-10, orthogonalized to Relationship Time 0 borrower and loan characteristics.

3. Relationship Time is the number of loans a borrower has received from lenders in the syndicated loan market in the past.

4. Time Trend is the facility origination year, entered linearly.

5. Control variables are: $Z$ score, default probability, $\log$ (assets), secured and revolver indicators, and loan maturity. 


\section{Table 5: Does the Market Charge Good Borrowers Less or Bad Borrowers More Over Time?}

This table reports OLS regression of syndicated loan facility interest rates on the orthogonalized proxies for borrower creditworthiness, allowing for different slopes above and below zero. The sample is LPC Dealscan facilities originated between 1986 and 2003 to borrowers appearing in the Compustat-CRSP Merged database, for whom loan terms and each proxy is available.

\begin{tabular}{|c|c|c|c|c|}
\hline \multirow[t]{3}{*}{ Dependent variable: } & \multicolumn{4}{|c|}{ Interest Rate over LIBOR (bps) } \\
\hline & \multicolumn{2}{|c|}{ Stock Market Proxy } & \multicolumn{2}{|c|}{ Ratings Proxy } \\
\hline & (1) & (2) & (3) & (4) \\
\hline Relationship Time & $\begin{array}{c}1.340 * * * \\
(0.445)\end{array}$ & $\begin{array}{c}3.751 * * * \\
(0.682)\end{array}$ & $\begin{array}{c}0.942 * * * \\
(0.360)\end{array}$ & $\begin{array}{c}2.329 * * * \\
(0.638)\end{array}$ \\
\hline$(\text { Proxy) })^{+}$x Relationship Time & $\begin{array}{c}-8.085 * * * \\
(1.891)\end{array}$ & $\begin{array}{c}-9.770 * * * \\
(2.183)\end{array}$ & $\begin{array}{c}-0.409 * * * \\
(0.134)\end{array}$ & $\begin{array}{c}-1.104 * * * \\
(0.159)\end{array}$ \\
\hline$-(\text { Proxy })^{-} \times$Relationship Time & $\begin{array}{l}-2.907 * \\
(1.683)\end{array}$ & $\begin{array}{c}-2.968 \\
(1.934)\end{array}$ & $\begin{array}{l}-0.149 \\
(0.097)\end{array}$ & $\begin{array}{c}-0.278 * * \\
(0.116)\end{array}$ \\
\hline Control variables & YES & YES & YES & YES \\
\hline Year FE & YES & YES & YES & YES \\
\hline Industry FE & YES & & YES & \\
\hline Borrower FE & & YES & & YES \\
\hline S\&P LT Debt Rating FE & & & YES & YES \\
\hline F test: equality of learning coeffs & 2.934 & 3.819 & 1.825 & 13.15 \\
\hline Prob $>$ F & {$[0.087]$} & {$[0.051]$} & {$[0.177]$} & {$[0.000]$} \\
\hline Observations & 8,673 & 8,673 & 9,458 & 9,458 \\
\hline R-squared & 0.553 & 0.787 & 0.595 & 0.774 \\
\hline
\end{tabular}

Standard errors clustered by borrower in parentheses.

$* * * \mathrm{p}<0.01, * * \mathrm{p}<0.05, * \mathrm{p}<0.1$

Notes.

1. The Stock Market Proxy is a borrower's [-21,+42]-day cumulative AR around 9/15/2008, orthogonalized to Relationship Time 0 borrower and loan characteristics.

2. The Ratings Proxy is a borrower's worst S\&P long-term debt rating over 2004-10, orthogonalized to Relationship Time 0 borrower and loan characteristics.

3. The proxies are separated into their positive and negative parts:

$$
\begin{aligned}
& (\text { Proxy })^{+} \equiv \mid \text { Proxy } \mid \times 1\{\text { Proxy }>0\} ; \\
& (\text { Proxy })^{-} \equiv \mid \text { Proxy } \mid \times 1\{\text { Proxy }<0\} .
\end{aligned}
$$

4. Relationship Time is the number of loans a borrower has received from lenders in the syndicated loan market in the past.

5. Control variables are: (Proxy) ${ }^{+}$, (Proxy) $)^{-}, \mathrm{Z}$ score, default probability, log(assets), secured and revolver indicators, and loan maturity. 


\section{Table 6: What Do Banks Learn About?}

This table tests whether the bank learning coefficient (on the Stock Market Proxy $\times$ Relationship Time interaction variable) is systematically closer to zero in deal years when the borrower was in a different industry or had a different CEO than 2008, the year in which the proxy is constructed. Panel A reports OLS regressions of syndicated loan interest rates on the proxy interaction variable, additionally interacted with an indicator variable for different SIC classification (column 1) and for a different CEO (column 2). Panel B reports cross-tabs of SIC industry reclassifications and CEO turnover, comparing the firm's status in the deal year vs. 2008. Sample is facilities originated between 1987 and 2003 to borrowers that were publicly traded both at time of loan and in 2008. Columns with CEO data restrict to ExecuComp borrowers only.

\begin{tabular}{|c|c|c|}
\hline \multicolumn{3}{|c|}{ Panel A: Regression results } \\
\hline \multirow[t]{2}{*}{ Dependent variable: } & \multicolumn{2}{|c|}{ Interest Rate spread over LIBOR (in bps) } \\
\hline & $(1)$ & $(2)$ \\
\hline \multirow[t]{2}{*}{ Relationship Time } & 0.808 & 0.72 \\
\hline & $(0.711)$ & $(0.663)$ \\
\hline \multirow{2}{*}{ Stock Market Proxy $\times$ Relationship Time } & $-5.560 * *$ & $-7.271 * *$ \\
\hline & $(2.214)$ & $(3.226)$ \\
\hline \multirow[t]{2}{*}{ Stock Market Proxy $\times$ Relationship Time $\times 1\{$ Different Industry $\}$} & 5.804 & \\
\hline & $(3.870)$ & \\
\hline \multirow[t]{2}{*}{ Stock Market Proxy $\times$ Relationship Time $\times 1\{$ Different CEO $\}$} & & $4.604 *$ \\
\hline & & $(2.761)$ \\
\hline \multirow[t]{2}{*}{ Stock Market Proxy } & 6.964 & 12.2 \\
\hline & $(5.967)$ & $(8.589)$ \\
\hline Control variables & YES & YES \\
\hline Year FE & YES & YES \\
\hline Industry FE & YES & YES \\
\hline F test: sum of learning coeffs $=0$ & 0.004 & 1.490 \\
\hline Prob $>$ F & {$[0.947]$} & {$[0.222]$} \\
\hline Observations & 8,673 & 4,579 \\
\hline R-squared & 0.553 & 0.559 \\
\hline
\end{tabular}

Standard errors clustered by borrower in parentheses.

${ }^{* * *} \mathrm{p}<0.01,{ }^{* *} \mathrm{p}<0.05,{ }^{*} \mathrm{p}<0.1$

\begin{tabular}{cccc}
\hline \multicolumn{5}{c}{ Panel B: Frequency } & Count of CEO and Industry Changes, Deal Year vs. 2008 \\
\hline & Same CEO & Different CEO & Total $^{\dagger}$ \\
\hline & 1,056 & 3,127 & $\mathbf{7 , 6 8 9}$ \\
Same SIC-2 code & 58 & 338 & $\mathbf{9 8 4}$ \\
\hline Different SIC-2 code & $\mathbf{1 , 1 1 4}$ & $\mathbf{3 , 4 6 5}$ & $\mathbf{8 , 6 7 3}$ \\
\hline Total &
\end{tabular}

${ }^{\dagger}$ The rows do not sum across because the "Total" column includes 4,094 non-ExecuComp firms.

Notes.

1. The Stock Market Proxy is a borrower's [-21,+42]-day cumulative AR around 9/15/2008, orthogonalized to Relationship Time 0 borrower and loan characteristics.

2. Relationship Time is the number of loans a borrower has received from lenders in the syndicated loan market in the past.

3. Control variables are: $\mathrm{Z}$ score, default probability, $\log$ (assets), secured and revolver indicators, and maturity. 